\title{
SOEP
}

SOEPpapers

on Multidisciplinary Panel Data Research

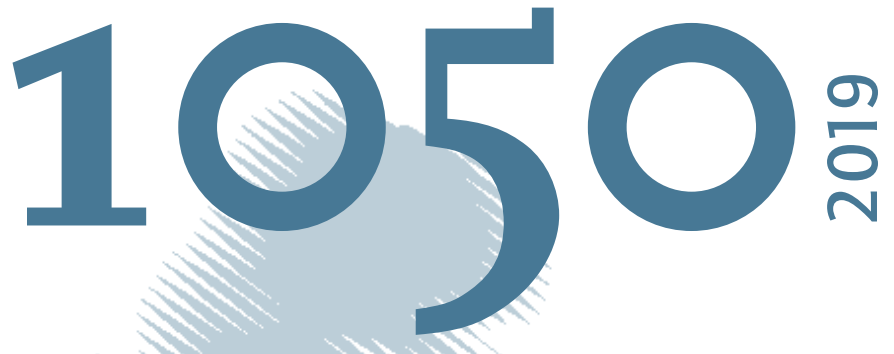

\section{Transitioning Towards More Equality? Wealth Gender Differences and the Changing Role of Explanatory Factors over Time}


This series presents research findings based either directly on data from the German SocioEconomic Panel (SOEP) or using SOEP data as part of an internationally comparable data set (e.g. CNEF, ECHP, LIS, LWS, CHER/PACO). SOEP is a truly multidisciplinary household panel study covering a wide range of social and behavioral sciences: economics, sociology, psychology, survey methodology, econometrics and applied statistics, educational science, political science, public health, behavioral genetics, demography, geography, and sport science.

The decision to publish a submission in SOEPpapers is made by a board of editors chosen by the DIW Berlin to represent the wide range of disciplines covered by SOEP. There is no external referee process and papers are either accepted or rejected without revision. Papers appear in this series as works in progress and may also appear elsewhere. They often represent preliminary studies and are circulated to encourage discussion. Citation of such a paper should account for its provisional character. A revised version may be requested from the author directly.

Any opinions expressed in this series are those of the author(s) and not those of DIW Berlin. Research disseminated by DIW Berlin may include views on public policy issues, but the institute itself takes no institutional policy positions.

The SOEPpapers are available at http://www.diw.de/soeppapers

\section{Editors:}

Jan Goebel (Spatial Economics)

Stefan Liebig (Sociology)

David Richter (Psychology)

Carsten Schröder (Public Economics)

Jürgen Schupp (Sociology)

Sabine Zinn (Statistics)

Conchita D'Ambrosio (Public Economics, DIW Research Fellow)

Denis Gerstorf (Psychology, DIW Research Fellow)

Katharina Wrohlich (Gender Studies)

Martin Kroh (Political Science, Survey Methodology)

Jörg-Peter Schräpler (Survey Methodology, DIW Research Fellow)

Thomas Siedler (Empirical Economics, DIW Research Fellow)

C. Katharina Spieß (Education and Family Economics)

Gert G. Wagner (Social Sciences)

ISSN: 1864-6689 (online)

German Socio-Economic Panel (SOEP)

DIW Berlin

Mohrenstrasse 58

10117 Berlin, Germany

Contact: soeppapers@diw.de

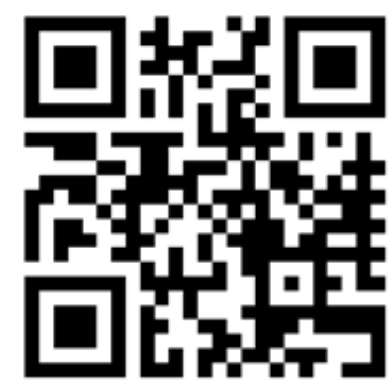




\title{
Transitioning Towards More Equality? Wealth Gender Differences and the Changing Role of Explanatory Factors over Time ${ }^{1}$
}

\author{
Eva Sierminska \\ Luxembourg Institute of Socio-Economic Research, DIW Berlin, GLO and IZA \\ Daniela Piazzalunga \\ FBK-IRVAPP , IZA and CHILD-Collegio Carlo Alberto \\ Markus M. Grabka \\ DIW Berlin
}

\begin{abstract}
:
The objective of the study is to investigate the changing role of explanatory factors of wealth and the gender wealth gap in Germany over the period 2002-2012 using individual level microdata from the German Socio-Economic Panel. The authors apply distributional decomposition methods and focus on the role of changes in labor supply, permanent income, portfolio composition, and marital status in this process. Results show that real mean wealth levels for the working age population have been decreasing for both women and men since 2002 and that the wealth gap has decreased by $13.5 \%$ to $30.700 €$. The growing labor market participation of women and the resulting occupational structure has a positive effect on women's wealth accumulation. In comparison to previous analyses, the authors use the panel dimension of the data and find that the role of permanent income is decreasing due to a reduction in the gender difference in permanent income and in gender differences in its returns.
\end{abstract}

JEL Classification: D31, D13

Keywords: wealth differences, gender, SOEP, decomposition analysis

\section{Corresponding author:}

Eva Sierminska, Luxembourg Institute of Socio-Economic Research

Avenue de la Fonte

L-4364 Esch-sur-Alzette

Luxembourg

E-mail: eva.sierminska@liser.lu

\footnotetext{
${ }^{1}$ We would like to thank for comments and suggestions the participants at several conferences and workshops. Additional results and copies of the computer programs used to generate the results presented in the paper are available from the corresponding author.
} 


\section{Introduction}

Given the increasing reliance of economic well-being on private assets, which also includes old age provisions in the form of pensions and retirement income, there is a growing interest in the study of private wealth. However, until recently the information about private wealth was scarce or non-existent in many European countries. With the availability of new data sources, ${ }^{1}$ this knowledge gap has significantly diminished: economic well-being in terms of wealth is less of an unknown nowadays. Research on wealth inequalities has shown that a substantial gender wealth gap exists and points to labor market factors as being the most important ones in terms of explaining differences in wealth holdings between women and men (e.g. Sierminska et al. 2010). The literature so far has been silent on the evolution of wealth in light of changes in the labor market. Our paper intends to fill in this gap. We focus on whether an increased attachment to the labor market and changing occupational structure allow women to catch up in terms of wealth accumulation and consequently, diminish the wealth gap. If so, this would further expand the importance of eliminating the gender wage gap for the wealth gap. We also consider other factors that can explain differential wealth accumulation such as, risk preferences and marital transitions to see whether these affect the existing trends.

Our focus is on Germany during 2002 and 2012. Several developments in this country make it an interesting case study. First of all, Germany was hit hard by the 2008/2009 financial crisis and the recession was recorded as one of the strongest to hit this country after World War II: its GDP dropped by more than 5\% in 2009 and this was felt across the different sectors in the economy (Eurostat, 2018). Germany's labor market also underwent substantial changes during this time. Since the year 2000, numerous labor market reforms were introduced (the so called Hartz reforms), which helped transform Germany from being at the tail-light of

\footnotetext{
${ }^{1}$ Notably, the availability of Luxembourg Wealth Study (LWS) and the Household Finance and Consumption Survey (HFCS) data.
} 
European countries with respect to low unemployment and economic progress to being a frontrunner (e.g. Dustmann et al., 2014; Brenke, 2015). ${ }^{2}$ Women's labor market participation grew significantly from 55.9\% in 2003 to $62.5 \%$ in 2013 (Brenke, 2015) reaching European levels. Entry into employment allowed women to earn wages that could have affected their savings and, consequently, enabled larger wealth accumulation, ceteris paribus. During the crisis, men were initially severely affected by income losses. The manufacturing and engineering industry in Germany - which employs a majority of men - shrank by almost 20\% (Burda and Hunt, 2011). ${ }^{3}$ The precarious labor market conditions for men at the beginning of the crisis and potential effects in the mid-term could have left women as the sole earner of the family, increasing their importance in the path of wealth accumulation.

A priori, our expectations would be that the financial crisis had a substantial impact on financial assets and net worth of private households. In particular, men's wealth would be affected more, given their higher wealth levels preceding the crisis and their larger income losses during the crisis due to labor market contraction. Yet, over the whole period in Germany there was almost no effect on the property market and the stock market recovered rather quickly (Grabka, 2015). Thus, wealth changes observed during this time period would rather be related to changes in the accumulation pattern than to the valuation of assets.

The motivation for our paper is several fold. First, the increasing role of private assets in ensuring one's standard of living brings us to investigating the role of wealth in within gender inequalities. Second, given that women on average live a few years longer than men (Eurostat, 2015) and they have lower public pension entitlements (the gender pension gap for mandatory pensions is about $34 \%$ in OECD countries - OECD, 2012), there is pressure for women to take

\footnotetext{
2 The effect was a significant drop in unemployment rates from $10.5 \%$ to $6.9 \%$ in 10 years (between 2003 and 2013).

${ }^{3}$ The manufacturing and engineering industry made heavy use of short-term compensation during this time. The basic idea of short-time compensation is that a firm with financial difficulties can apply for financial aid from the Federal Employment Agency to prevent the need for layoffs. In return, the firm has to reduce working hours and pay. The replacement rate is $60 \%$ for single workers and $67 \%$ for workers with dependents.
} 
care of their own private wealth. We monitor the evolution of their situation. The concern with lower levels of wealth is further reinforced by the growing number of single-headed female households (UNECE, 2014; US Census Bureau, 2014) and in particular elderly women, who suffer more than men from old-age poverty (OECD, 2012). Third, as labor force participation of women heavily increased, we want to better understand if and how this factor contributed to changes in the gender wealth gap given that this has been found to be one of the most important factors contributing to this gap in the past literature. Fourth, we intend to investigate which other factors contribute to the changing wealth gap in Germany.

We first set out to investigate which factors contributed to the changing individual wealth levels in Germany before and after the Great Recession. These include a focus on whether the changing labor market supply of women had a significant impact on their wealth accumulation considering the full occupational structure for women and men. We assert that labor market variables are more important for women in wealth accumulation than previous found. In doing so, we extend the work done by Sierminska et al. (2010) and provide a panel perspective of the wealth evolution by factors of women and men in Germany. Subsequently, we hypothesis that labor market factors will explain a smaller part of the gap than before. Thus, in the second part of the paper, we extend the existing literature on the gender wealth gap and perform a detailed decomposition that points to the changes of the gap throughout the wealth distribution. Our next hypothesis refers to the fact that the role of labor market variables will be differ depending on the jobs taken and thus, will differ across the distribution We also identify other factors that are now important in explaining the gap. Finally, in the concluding section, we discuss whether the increased participation of women in the labor market is sufficient in reducing the wealth gap.

Our ability to perform this analysis is governed by the availability of unique data. The German Socio-Economic Panel (SOEP) is one of rare data-sources that collects wealth 
information at the individual level and makes intra-household comparisons possible. With three waves that include wealth information available, we take a pre-crisis (2002-2007) and postcrisis (2007-2012) look at gender specific wealth accumulation.

\section{Conceptual background and Literature review}

Wealth is accumulated according to the standard life-cycle model, where the stock of assets in the current period is the outcome of past decisions regarding investment, labor market outcomes, savings and consumption. ${ }^{4}$ In this model, wealth is accumulated during the working stage of one's life in order to be decumulated during retirement. Thus, the process of wealth accumulation before and after retirement differs in its purpose and exhibits different patterns. ${ }^{5}$ As discussed in Sierminska et al. (2010), differences in any factors affecting wealth accumulation will give rise to a different wealth trajectory and consequently a different portfolio structure. Consequently, any type of macro-economic or life-shock will have a differential impact on individual portfolios depending on their structures. Women and men have been found to have systematically different portfolio structures, because they save differently, they invest differently with diverging levels of returns (Chang, 2010; Lersch, 2017a), and they have differential earnings resulting from a varying attachment to the labor market (Xiao, 1995; Sierminska et al., 2010). For example, women are significantly less likely to own business assets (e.g. Austen et al., 2014) and are more likely to have less risky assets than men (Sundén and Surette, 1998). One explanation for this finding is that women and men differ in risk attitudes, with women being less risk tolerant and more risk-averse (Bajtelsmit and Bernasek, 1996; Jianakopolos and Bernasek, 1998; Cartwright, 2011). A higher risk aversion for women could reduce the expected return of their portfolio and at the same time shelter them from unexpected asset fluctuations that occurred during the Great Recession.

\footnotetext{
${ }^{4}$ A discussion of the economic rationale of wealth accumulation can be found in Rossi and Sierminska (2018).

${ }^{5}$ Our focus is on the former.
} 
Thus, a lower risk aversion may have allowed women to lose less (or maybe even allowed to gain) during the Great Recession in Germany compared to men, but reduce their gains in the face of recovering markets. The saving patterns are also different among women and men (Fisher, 2010), and women have more difficulty with access to credit (Alesina et al., 2013). Fewer women are also in the position to pass-down self-made wealth compared to men (Edlund and Kopczuk, 2009). Addionally, financial literacy influences investment decisions (e.g. Huston 2010; Lusardi and Mitchell, 2008), and it has been shown that women have lower financial knowledge than men, which leads them to have more conservative investments patterns (Almenberg and Dreber, 2015).

Another aspect that could affect the differential changes in wealth levels are marital status transitions. Marriage is a wealth-enhancing institution because married couples benefit from the joining of assets, dual incomes, and lowered expenses due to economies of scale (Vespa and Painter, 2011; Ruel and Hauser, 2013; Lersch, 2017a; Lersch et al., 2017). On the other hand, substantial income and wealth losses occur due to divorce (Jarvis and Jenkis, 1999; Zagorsky, 2005; Addo and Lichter, 2013). However, Sierminska et al. (2010) showed that a gender wealth gap already exists prior to marriage on the basis of age alone, as man in Germany are on average 3 years older than their wife. Moreover, parenthood, within or outside of marriage, has a negative effect on women's employment and wages, impairing their individual wealth accumulation (Yamokoski and Keister, 2006; Lersch et al., 2017), while there exists a marriage premium for men in wages.

One of the most important factors that explains male-female differences in wealth accumulation are labor market differences. Individuals that work in stable, full-time, higher prestige occupations will consistently earn greater income (and have higher permanent income), which will improve their ability to save (Ruel and Hauser, 2013). Lower labor market participation rate of women, their lower working hours, the glass ceiling and the ever existing 
gender pay gap, ${ }^{6}$ impairs the wealth accumulation for women (Warren et al., 2001). Thus, even holding saving rates constant, women are expected to accumulate lower levels of wealth. Moreover, women and men tend to cluster in occupations with different perspectives for advancement and different exposures to labor market fluctuations. Consequently they could be differentially exposed to the labor market consequences of the Great Recession.

Besides these different factors one needs to keep in mind the marriage law and its consequences on wealth accumulation. The standard marital property regime in Germany (likewise in Greece and Cyprus) is that of joint ownership of accumulated capital during marriage and wealth accumulated prior to marriage will remain in the hands of the original owner and will not be affected by a divorce. Inheritances during marriage are also not considered to be accumulated jointly and thus will remain fully in the hands of the successor. ${ }^{7}$ This is in contrast to the majority of European countries ${ }^{8}$ where the standard marriage law is community of property, i.e. all premarital wealth is wholly owned by the respective partner, while all wealth accumulated during marriage belongs to both partners. Another variant is the separation of property regime, which is applied in the UK and Ireland. These different marriage regimes will most likely have consequences on intra-partnership bargaining power and the way wealth is accumulated during marriage. For Germany this implies, that wealth differences, which already exist within couples before marriage will further persist and impede wealth accumulation for women.

Another environmental factor affecting wealth accumulation is the fiscal regime in Germany, though, there are a priori no gender-sensitive rules. However, due to the joint

\footnotetext{
${ }^{6}$ Irrespective of the increased labour market participation of women, Germany stands out with respect to the gender pay gap. The raw pay gap in Germany is one of the highest in the European Union with a value of about $21 \%$ in 2016, remaining stable since 2001 (Federal Statistical Office, 2018a).

${ }^{7}$ However, this is true for the (monetary value) of the original inheritance only and excludes eventual capital gains or added value. Marriage contracts can deviate from these standard regulations in divorce law.

${ }^{8}$ This is Belgium Slovenia, France, Luxembourg, Spain, Estonia, Latvia, Malta, Czech Republic, Poland, Hungary, Italy, Lithuania, Croatia, Bulgaria, Portugal, Slovakia and Romania (see Rotoni 2015).
} 
taxation of couples there are negative employment effects for married women, which is are particular strongin combination with marginal employment (Steiner and Wrohlich 2004). Again, against the background of the current marriage law in Germany, this has different effects on wealth accumulation for men and women.

Finally, social policy instruments can have an effect on wealth accumulation. Here one can highlight the so-called parental allowance introduced in 2007. Up to 2007, the former childraising benefit granted only a small lump of 300 euro per month for the parent who raised a child. The new policy instrument provides 67 percent of the former net labor income thus, possibly providing an incentive for women to be in the labor force prior to becoming mothers and slightly alleviating the parent penalty for higher paying individuals.

Most of the above-mentioned papers are all confronted with the problem that individual wealth data was not available and the analysis of gender wealth differences has typically been conducted on men and women in single households (e.g., Schmidt and Sevak, 2006; Yamokoski and Keister, 2006; Chang, 2010; Ruel and Hauser, 2013; Austen et al., 2014) or on selected wealth components (see Warren, 2006). ${ }^{9}$ However, without individual wealth information it is not possible to determine asset ownership by each individual within married couples or multi-person households.

So far, only a limited number of papers analyze individual net worth, such as Frick et al. (2007), Sierminska et al. (2010), Grabka et al. (2015), and Lersch (2017a, 2017b), making use of unique individual wealth data from the German Socio-Economic Panel study. These authors show that there is a significant gender wealth gap in Germany, not only between single men and women, but even within married couples. The main conclusion from these papers is that the large gender pay gap in Germany and low women's labor market participation in the most

\footnotetext{
${ }^{9}$ A few surveys ask for selected individual wealth components like pension wealth, e.g. the Health and Retirement Study (HRS) conducted by the University of Michigan or the UK Family Resources Survey (FRS).
} 
recent past gave rise to higher wealth accumulation for men than for women. None of these papers examine the impact of changing labor market supply of women and men on the dynamics of the wealth gap. This is where our paper comes into play.

\section{Data}

The German Socio-Economic Panel (SOEP) is a representative, longitudinal survey on individuals in private households (Goebel et al., 2019). The survey started in 1984 in West Germany, and extended to East Germany in 1990. Every year, about 15,000 households are interviewed $(25,000$ people). In 2002 , there was a boost of higher-income people to better capture the upper margin of the income and wealth distribution. There were other refreshment samples in 2006, 2010, 2011, and 2012, but the refreshment of 2012 did not collect information on wealth. Although the SOEP has a special high-income sample, it does not, similarly to most household surveys, capture the very rich. In fact, the person with the highest net worth in the sample only holds almost 63 million euro in 2002 . We return to this in the last section of the paper.

Information on socio-demographic characteristics, as well as, information on education, employment, earnings, income, household composition, health and satisfaction are collected every year. In addition, there are topic modules, which are replicated about every 5 years. We use the theme modules, which contain information on individual wealth mostly from 2002 , 2007 and 2012; the initial sample has more than 23,000 observations in 2002, about 21,000 in 2007 and slightly more than 18,000 in 2012.

\section{Sample}

We use two different samples in the paper. The first sample is used to provide a descriptive picture representative of the German population in 2002, 2007 and 2012 - in order to show the actual evolution of wealth over time (Cross-sectional sample with cross-sectional weights). 
In the second sample, we use the panel component of the SOEP in order to track the evolution of wealth over time. First, to provide a 'pre-crisis' picture of wealth we track those present in the 2002 and the 2007 samples (Panel sample 2002-2007). Next, we have a second sample of those present in the 2007 and the 2012 surveys (Panel sample 2007-2012). These two samples (which are used for Table 2 onwards) have the advantage that they follow individuals over 5 years - not only their wealth, but also other characteristics. The latter sample also includes a refreshment sample, which takes into account the changing demographic structure of the population. We opted not to use a combined panel sample over the three waves as the longer a balanced panel population is, the more selective it is by neglecting young adults, the deceased and those who migrate. Additionally, attrition hampers a meaningful analysis. Thus, we have two samples that point to some clear findings. For the panel sample, we use panel weights to control for selective attrition, which are made available by the data provider.

In both of our samples we focus on the population 25 to 64 years old, in order to capture individuals during the time spent in the labor market, ${ }^{10}$ i.e. the accumulation stage in the standard life-cycle model.

\section{Outcome variable}

The German SOEP contains information about 10 different wealth components: own property, other real estate, mortgages on owner-occupied property, other mortgages, financial assets, business assets, tangible assets, building loan agreements, private insurances, and consumer credits. All its components are in market values of the day of the interview. Our main dependent variable is net total wealth the sum of assets minus total debts, in 2010 real prices. In SOEP, the missing values for wealth are corrected with imputation techniques (see Grabka and Westermeier, 2016). Notice that SOEP does not explicitly survey cash holdings or money in

\footnotetext{
${ }^{10}$ A small number of people under 64, pensioners in period 1, are excluded from the sample (about 150-200 observations in total).
} 
checking accounts. It also does not survey wealth in the form of durable commodities such as vehicles or furniture or the value of patents.

In contrast to other wealth surveys, the SOEP asks each adult respondent to provide information about her/his individual assets and debts, in order to get an information about the rightful owner. If a wealth component is owned by several members, they are asked to report their individual share value in percent. A potential benefit of surveying wealth information at the individual level is the higher accuracy of the data compared to those from surveys that rely exclusively on the answers of single reference person. This is particularly true for multi-person households. A potential drawback of the individual approach is the higher probability of nonresponse.

We apply a $0.1 \%$ top coding, and the inverse hyperbolic sine transformation (Pence, 2006), useful to mitigate the effect of outliers and to deal with the skewness of the wealth distribution (in comparison to the log transformation, the inverse hyperbolic sine transformation allows for the inclusion of negative and 0 values). ${ }^{11}$

\section{Control variables}

The SOEP allows for a rich set of control variables. We outline the details regarding their construction in Appendix B and list them below. We use "lagged" control variables, i.e. from the previous period, and construct variables that identify changes over the previous 5 years. We control for demographic variables describing the migratory background, age, age squared, living in West or East Germany, lagged level of education, the number of children below age 5 in the household, number of marriages, length of the current marriage, changes in marital status; labor market and income variables, such as number of months spent in full-time and in part-time work in the previous 5 years, long-term unemployment in the previous 5 years,

\footnotetext{
${ }^{11}$ It is defined as $\log \left(\mathrm{y}_{\mathrm{i}}+\left(\mathrm{y}_{\mathrm{i}}{ }^{2}+1\right) / 2\right)$ and since, except for very small values of $\mathrm{y}$, the transformation is approximately equal to $\log \left(2 \mathrm{y}_{\mathrm{i}}\right)$, it can be interpreted in exactly the same way as a standard logarithmic dependent variable.
} 
(inverse hyperbolic real) permanent income (defined using the 5-years average), inverse hyperbolic value of household windfall income over the previous 5 years (inheritance/bequest/lottery); and lagged risk preference and the share of financial assets. In a second specification, we also include wealth/portfolio variables that identify $(0 / 1)$ whether a household received inheritance (bestowals) or lottery in the previous 5 years, was able to save some money in the previous 5 years, changed property ownership; changed consumer credits ownership; as well as lagged tangible assets, lagged property debts, changes in stocks (at the household level), and an indicator variable for being worried about personal economic/financial reasons.

\section{Methods}

To answer our research questions, we first, focus on the determinants of wealth levels over the 2002-2012 sample period, separately for men and women, and then investigate the wealth gap through decomposition techniques.

\section{Changing determinants of wealth levels}

To analyze the determinants of wealth over time, we estimate a wealth function on selected control variables for the two time-periods using standard OLS techniques. Taking advantage of the panel dimension of our data, we take into account changes in select variables rather than levels as the former ought to be better predictors of the structural change we are interested in. The estimated equation is:

$$
w_{t}=\alpha_{t}+\beta \boldsymbol{T}_{t}+\gamma \boldsymbol{Z}_{t-1}+\delta \Delta \boldsymbol{C}_{\boldsymbol{t}}+\varepsilon_{t}
$$

where $w_{t}$ is the level of (inverse hyperbolic real) net wealth in a given year; $t=\{2007 ; 2012\}$, $t-1=\{2002 ; 2007\}$

$\boldsymbol{T}_{\boldsymbol{t}}$ is a vector of the control variables (age, sex, etc.) mentioned above observed in the second period (i.e. in 2007 for the comparison 2002-2007, and in 2012 for the comparison 2007-2012). $\boldsymbol{Z}_{t-1}$ is a vector of control variables observed in the first period (i.e. in 2002 for 
the comparison 2002-2007, and in 2007 for the comparison 2007-2012), referred to as "lagged variables" such as, level of education, occupational status, and risk-loving/risk aversion. $\Delta \boldsymbol{C}_{\boldsymbol{t}}$ is a vector of variables indicating changes in control variables between $t-1$ and $t$, sometimes referred to as "change variables", and here includes e.g. changes in marital status. $\varepsilon_{t}$ is a random error normally distributed. $\beta, \gamma, \delta$ are vectors of parameters to be estimated by OLS.

This is a typical formulation for the evolution of wealth found in other studies, but it is augmented by the lagged variables and the change variables in order to capture the time factors in the regressions. It also includes a rich list of labor market variables that will allow us to answer our questions.

We also estimate a second specification (the "long" specification), in which we add the wealth/portfolio variables mentioned above. In the robustness section, we discuss additional specifications.

Equation (1) is estimated separately for men and women, for the periods 2002-2007 and 2007-2012.

\section{The gender wealth gap over time}

To describe the gender wealth gap over time, before and after the crisis, we first apply the Oaxaca-Blinder (OB) method (Blinder, 1973; Oaxaca, 1973), which allows for a detailed decomposition of mean wealth for women and men, and then the Firpo, Fortin, Lemieux detailed decomposition (Firpo et al., 2009) for the whole distribution in the two periods. We describe both methods below.

The Oaxaca-Blinder decomposition relies on the estimation of equation (1) for men and women separately, that we recall here:

$$
\begin{aligned}
w_{t} & =\alpha_{t}+\beta \boldsymbol{T}_{\boldsymbol{t}}+\gamma \boldsymbol{Z}_{t-1}+\delta \Delta \boldsymbol{C}_{\boldsymbol{t}}+\varepsilon_{t}= \\
& =\vartheta \boldsymbol{X}_{\boldsymbol{t}}+\varepsilon_{t}
\end{aligned}
$$

where included control variables remain as described above. 
Then, the OB decomposition of the differences in wealth for women and men is as follows:

$$
\begin{aligned}
g_{t} & =\bar{w}_{t}^{M}-\bar{w}_{t}^{F}= \\
& =\left(\overline{\boldsymbol{X}}_{\boldsymbol{t}}^{\boldsymbol{M}}-\overline{\boldsymbol{X}}_{\boldsymbol{t}}^{F}\right) \hat{\vartheta}^{M}+\overline{\boldsymbol{X}}_{\boldsymbol{t}}^{\boldsymbol{M}}\left(\hat{\vartheta}^{M}-\hat{\vartheta}^{F}\right)
\end{aligned}
$$

where $M=$ male, $F=$ female. The first component captures the average wealth differential which can be attributed to differences in characteristics (the "explained" effect), while the second one captures differences in returns, i.e. coefficients (the "unexplained" effect). The procedure also allows for a detailed decomposition, which identifies the contribution of each individual explanatory variable to the gap, differentiating, in turn, between the corresponding effects associated with endowments and returns.

\section{Decomposition of the gender wealth gaps over the entire distribution}

For the detailed decomposition of the gender wealth gaps across the wealth distribution, we use the technique introduced by Firpo, Fortin, Lemieux (2009). It allows differences between two distributions of a variable to be decomposed and the individual contribution of each explanatory variable to be considered in the analysis via the characteristics and returns components. In our case, it will allow us to identify the explanatory factors of wealth gaps and better understand how the differences in their distribution and returns differ over time (characteristics and returns) and contribute to the gender wealth gap in Germany. Unlike the DiNardo, Fortin, Lemieux (1996) method, it is not based on a reweighting technique and does not require computing a sizeable number of reweighting factors to compute the various elements of the detailed decomposition. ${ }^{12}$

The Firpo, Fortin, Lemieux method is regression based and can be applied in a similar way as the $\mathrm{OB}$ method. The technique relies on the estimation of a regression, where the

\footnotetext{
${ }^{12}$ A discussion of the advantages and limitations of both methods is found in Fortin et al. (2011).
} 
dependent variable is replaced by a recentered influence function (RIF) transformation. This allowsany distributional statics to be decomposed based on the regression results.

In our case, we will focus on the differences in quantiles:

$$
\Delta_{Q \tau}=\left(\bar{X}^{M}-\bar{X}^{F}\right) \hat{\vartheta}^{M}{ }_{Q \tau}+\bar{X}^{M}\left(\hat{\vartheta}^{M}{ }_{Q \tau}-\hat{\vartheta}^{F}{ }_{Q \tau}\right)
$$

where $\Delta_{Q \tau}$ is the difference in quantile (or other statistic) $\tau$ of the wealth distribution. $\bar{X}^{M}$ and $\bar{X}^{F}$ are, as before, the average observed characteristics for men (M) and women $(\mathrm{F}) ; \hat{\vartheta}^{M, F}{ }_{Q \tau}$ are the coefficients obtained from the regression of the RIF variables of quantile $Q \tau$ on the set of explanatory variables for men $(\mathrm{M})$ and women $(\mathrm{F})$. As in the OB decomposition, the first term of equation (4) captures the effect on the gap between the distributions caused by differences in characteristics (explained component). The second term corresponds to the effect of the coefficients in which the contribution of each individual explanatory factor can be distinguished.

\section{Wealth in Germany and its determinants: A descriptive look}

Wealth levels: According to Table 1, real mean wealth levels are decreasing since 2002 for both women and men. ${ }^{13,14}$ As discussed by Grabka and Westermeier (2015) the decrease is mainly due to a reduction of nominal property prices, which make the bulk of individual wealth. The average wealth gender gap for the population 25-64 hovered around 35,500 Euros; it declined to 33,000 Euros in 2007 and declined further to about 30,700 in 2012, with an overall reduction of almost 5,000 Euros, i.e. a reduction of $13.5 \%$. Indeed, the decline in net worth was larger in absolute value for men than for women (9,800 Euros versus 7,600 Euros, in 20022007; 9,000 Euros versus 6,500 Euros, in 2007-2012). The effect at the median confirms the tendency, with a total reduction of about 3,000 Euros in the median gender gap (2002-2012).

\footnotetext{
${ }^{13}$ These results are based on the cross-sectional sample representative of the German population in the respective years and are an appropriate description of the gender wealth gap in Germany. These descriptive findings are confirmed by the Income and Expenditure Survey (EVS) of the German Federal Statistical Office (2018b).

${ }^{14}$ As explained in the Data section, the results for the panel samples used in the empirical analysis, while they can be used for the regressions, slightly differ and are only partially comparable.
} 
However, while in the pre-crisis period, median wealth for men decreased by about 6,700 Euros and by about 3,000 Euros for women, in the subsequent period, the reduction was very small for both. Thus, at the median the wealth gender gap remains virtually unchanged between 2007 and 2012. The different trends in terms of the median and mean gap during the second period suggest differential wealth changes along the wealth distribution for women and men and confirm the need for decompositions beyond the mean. We will explore the sources of this differential change as outlined in the previous sections.

Demographic variables and marital status: Table 2 provides the descriptive statistics in the sample used for the empirical analysis. Women are slightly younger, have more children, and compared to men a smaller share of them has a university degree, although the probability of having a university degree increases for both of women and men over time. When it comes to marital changes over the last 5 years, we find that in 2002/07 there is a small gap in favor of women in terms of who remains married. Men are also more likely to remain never married, but this rate is increasing for both men and women (25-30\% versus $18-23 \%)$.

Labor market changes: Women increased the number of months spent working in fulltime employment (by about 4 months in the last 5 years) and decreased the number of months spent in part-time employment (over two months). We observe a large drop in the share of women that are not in employment (by 6 ppt). Thus, since 2007 women are entering the labor market as full-time rather than part-time workers. Analogous numbers for men are not changing much. The number of men and women in long-term unemployment is decreasing.

In terms of occupations, women are for the most part entering white collar jobs and leaving blue collar jobs. Their permanent income has increased by about 2,000 Euros (up to 18,000 Euros) thanks to their increased labor market participation and changes in occupational structure. Permanent income for men remains about double this amount (34,000 Euros). 
Wealth portfolios and Risk: Table 2 and Table 3 also provide information on movements occurring in the wealth portfolio of women and men and over time. A changing wealth portfolio could be evidence of changing wealth levels and to some extent explain the observed differences. The tables indicate that women have a lower preference for risk than men. Both men and women save regularly in a similar fashion. The household level inheritances and gifts received decreased for men by about 20,000 Euros on average compared to the previous period, while women's is not changing although exceeding that of men's. ${ }^{15}$ Table 3 indicates that men in 2012 are more likely to own their house than women (by about 4 ppt) and nearly every type of asset (other real estate, financial, business, and tangible) as well as debt (building loan and private insurance, consumer credits).

Summary: Thus, women's labor market attachment, education and participation in white collar employment could be driving their increasing permanent income and thus affecting the way their wealth has been changing. Other aspects, which could also affect wealth levels, are changes in marital status and the changing composition of the portfolio.

\section{Results: multivariate analyses}

\section{Wealth levels over time: the changing role of explanatory factors}

At the outset of the analysis, we estimate a wealth equation in order to isolate the factors that could affect wealth levels differentially for women and men. We regress the inverse hyperbolic sine of wealth in the two periods on multiple explanatory factors as specified in equation (1). ${ }^{16}$ We perform robustness checks in the following sub-section. Table 4 shows the results for the determinants of wealth over time and across genders. We focus the discussion on the main variables of interest: labor market and income, risk and portfolio, and marital status.

\footnotetext{
${ }^{15}$ Receiving inheritances or lottery winning are rather rare events for the observed population, and these changes should be interpreted with caution.

${ }^{16} \mathrm{We}$ also performed the same regressions with changes in wealth as dependent variables, but the results do not differ significantly. For simplicity, we decided to retain only one specification.
} 
Demographic variables: Being a migrant has a significant negative effect on wealth for both men and women. Usually, one can argue that this is due to differences in the labor market (possibly discrimination), however we control for this aspect. Another explanation is that in Germany, a migrant "disadvantage" affecting wealth accumulation exists, in addition to the one stemming from the labor market (as has been well documented previously, for example, in Bauer et al. 2011 and in Mathae, Porpiglia and Sierminska, 2011), which in part may be due to remittances, which we do not control for in the paper. However, the effect is declining over time, which could also suggest the changing composition of migrants over time. Living in East Germany is also a strong factor determining wealth accumulation, which impairs absolute wealth changes due to persistenly lower earnings and lower wealth levels in that formerly socialist region.

The higher the educational level, the higher is absolute wealth. Besides yielding higher earning profiles, higher education is associated with higher financial literacy, which may facilitate better investment decisions. Having a university education seems to be more beneficial for women than for men when it comes to wealth, although the impact for men has substantially increased.

Labor market and income: As discussed, Germany underwent some interesting labor market changes over the past decade and we examine these with particular interest. Apart from labor supply, we also examine occupations. Full-time employment, which facilitates savings on a regular basis, has a positive effect on wealth. For women the effect disappears in 2012, when the effect of occupations and of permanent income becomes stronger (and significant for part-time employment). Long-term unemployment has an increasing negative effect on wealth accumulation for men and a decreasing negative effect for women. Indeed, income losses due to job losses are often offset by reduced saving or dissaving. 
An interesting effect can be observed to women who are not employed. While in 2007 this effect if insignificant, it becomes highly significant in 2012. This can be explained by a new policy instrument called parental allowance introduced in 2007. This new allowance is in favor of women with higher earnings as they now receive roughly 67 percent of their former net labor income. Up to 2007, the former child-raising benefit granted only a rather small lump sum.

Being self-employed has an increasing positive effect on wealth for both sexes (stronger for women). When it comes to occupations, it seems that the type of occupation chosen is particularly important for women, as a wealth determinant with the effect becoming stronger over time. Being a white collar worker is comparatively a stronger determinant of wealth compared to being a blue collar worker with the effect being stable for men and doublingfor women in the second period.

Permanent income has a positive and significant, albeit decreasing effect on wealth for men. For women, the effect becomes significant in 2012, reducing the overall gap of income returns.

Marital status changes: Changes in marital status could have a substantial effect on wealth levels. Divorce, which is costly, has a strong negative effect on wealth, and the effects are of similar magnitude for women and men. Although widowhood is expected to bring a positive effect on wealth, in our sample - which focuses on those in the labor market and consequently is fairly young - there is no significant effect. As discussed in Section 2, one would expect a positive effect for those getting married compared to those unmarried, as both partners now profit from the joining of assets, dual incomes, and lowered expenses from economies of scale. However, here our reference category is always married, signifying that those with longer marriage tenure are as well off or slightly better off than newly married couples. The effect diminishes for women. One potential explanation for this finding could be 
that marriage usually coincides with childbirth and finding a new home, these additional costs may interfere with the wealth accumulation process. It can also be that the number of marital status changes in the 5 years is too small to identify significant changes. We observe a significant negative effect for those that are always never married or stayed single, ${ }^{17}$ with larger coefficients for women.

The number of marriages has a negative effect on wealth levels, which is stronger for men. Marital property regime is in place in Germany and women may somehow be compensated due to divorce. The negative effect increases over time and more so for women, possibly due to their increasing contribution to the settlement in case of divorce.

Portfolio effect: The change in wealth also depends on the performance of the portfolio and, as seen from Table 3, this is different for women and men. If the portfolio consists of risky assets with a high expected return it will most likely perform better during an expansion (i.e. 2002-2007) compared to a financial crisis (i.e. 2007-2012), while a less risky portfolio with low expected returns would exhibit lower losses as well as lower gains. A larger share of financial assets contributes positively to wealth and the effect is stronger for men (although increasing for women). This confirms the fact that women have a larger share of assets in real estate and possibly a less risky portfolio. In the Appendix Table A.2, we include portfolio controls to examine the effect of portfolio decisions on the direction of wealth. These controls include variables relating to property, consumer debts, and stocks. ${ }^{18}$ In accordance with the literature, homeowners (reference category) have the highest wealth levels. Renting and selling

\footnotetext{
${ }^{17}$ Note that we distinguish between never married and single individuals (divorced, separated, and widowed).

${ }^{18}$ In the first specification (Table 4), we try to isolate the influence of individual characteristics on wealth accumulation, while in the second specification (see Appendix Table A.2, we focus on how differences in the portfolio composition affect wealth accumulation, when controlling for other relevant control variables. When adding portfolio variables, other controls have smaller importance, both in terms of magnitude and of significance, and this is not surprising, as wealth levels and portfolio composition are highly interrelated.
} 
property has a negative effect of similar magnitude with the effects being stronger for women and increasing over time among property sellers. Newly acquired property also has a somewhat stronger, negative effect for women. Compared to people that have consumer debts in both periods, those that get rid of consumer debts show a positive wealth change, as they are forced to pay back their loan on a regular basis. Stock owners also seem to have higher levels of wealth compared to those that do not, and the effects are similar for women and men. Thus, it seems that wealth differences stem more from wealth levels and how the money is invested and not specifically that there is a gendered effect on wealth, which would stem from differential returns of some kind. The gender specific effects of the portfolio composition on wealth that are observed are very small for the main components: property, consumer credit, and stock.

\section{Robustness checks}

As a robustness check on the determinants of wealth changes, we also estimate equation (1) without controlling for the occupational status. The results for our labor market variables remain robust in this exercise (Table A.3).

We also estimate equation (1) only for those that were married in $t-1$, to investigate the role of spouse/household characteristics that are not available for single people (the results are available in our working paper). Our results confirm the association between labor market participation and wealth, although the type of occupation become less important, particularly for women and particularly in the second period. With respect to the changes in marital status the results are also confirmed.

\section{Comparing the gender wealth gap in different periods}

Having shown that both labor market participation is changing for women and that there is in fact a changing role of labor market, occupations and income variables that could explain the changes in wealth levels for women and men, we move onto investigating to what extent they contribute to explaining the wealth gap over time in Germany. 
Previous work showed that labor market factors contribute a substantial amount to explaining the gender wealth gap across the distribution (Sierminska et al., 2010). We investigate this further by incorporating additional covariates and examining this both at the mean and across the distribution. Although the process of women's increased labor force participation is not completed, we may nevertheless see some notable changes.

\section{Oaxaca-Blinder decomposition}

The Oaxaca-Blinder decomposition of the gender wealth gap for the overall population is presented in Table 5. First of all, the wealth gap is largely due to differences in income (2007) and in labor market outcomes (2012). The differences in returns reduce the gap (the unexplained component is negative). The explained portion decreases by about one third, and the unexplained component, which is negative, declines by about one-half. In other words, differences in characteristics between men and women decline from one period to the next and so do the differences in returns, which favor women. Thus, there seems to be a move toward more equal wealth accumulation in terms of both characteristics and returns, although the difference in returns, which benefited women decline more than the differences in characteristics, which benefit more men.

In 2007, age, education, income, number of marriages and length ("other marital variables") contributed to explaining the gap. The differences in age between women and men stopped playing a role in explaining wealth differences in 2012, but the differences in returns associated with age contributed to a decrease in the gap substantially and significantly. The level of education contributed to explaining the differences in the gap similarly in both periods, but the returns only contributed to closing the gap in 2007 and no longer in 2012. Indeed, the higher return to education for women which is present in 2007, in 2012 is at the same level for both sexes. 
Labor market variables began contributing to the gap in 2012 as the share of women in full-time employment increased. In 2007, this was more the role of permanent income, whose role fell by one third in 2012. Moreover, Table 4 indicates that permanent income has a positive effect for men, while for women the effect is much smaller and only significant in 2012 . Consequently, the role of differences in permanent income levels substantially decreased from 2007 to 2012, as well as the role of returns to permanent income, which largely affected the gap before.

Apart from the less significant role of returns to permanent income and age, the greatest factor diminishing the gap in 2012 is the return to occupations. In both periods, differences in the occupational status are not significant in explaining the level of wealth, but the returns are. In 2012, they contribute to decreasing the wealth gap. In both periods, women are more likely to be in white collar jobs than before and more likely than men. We can imagine that as women continue to enter the labor market, into well-trained and consequently better paid occupations, and as their education level improves, their permanent income will have an increasing effect on closing the wealth gap, and differences in income levels and returns will continue to narrow.

In the next section, we investigate what is happening throughout the wealth distribution since factors may be offsetting each other at the mean (particularly those at the bottom of the distribution in relation to those at the top).

\section{Firpo, Fortin, Lemieux decomposition for the whole distribution}

The results from the detailed decomposition discussed hereafter serve to complement the OB decomposition at the mean. The results for the $25^{\text {th }}, 50^{\text {th }}$ and $90^{\text {th }}$ percentile in Table 6 (we do not examine the gap at the $10^{\text {th }}$ percentile as wealth levels are virtually non-existent) indicate the experiences of women (and men) differ throughout the distribution. First of all, the gap is largest at the bottom of the distribution $\left(25^{\text {th }}\right.$ percentile), and it decreases along the wealth distribution; however, at the bottom the gap decreases the most (in ppt and absolute value) 
between 2007 and 2012 and for the most due to declining differences in characteristics (in permanent income mostly). The overall differences in returns (which favor women) do not change substantially. These findings confirm our results at the mean - although with more detail. The detailed decomposition indicates that women now have an advantage in the returns to education, labor market participation and occupation, but unfavorable returns due to the marital status. There is a decline in the favorable returns to income for men throughout the distribution. At the median and at the top of the distribution, there are only very small changes in the wealth gap. Moreover, we should keep in mind that we miss the top-wealth, and our estimates of the top-gap are likely a lower bound and thus, we cannot satisfactorily address the issue of the glass-ceiling.

Additional factors with respect to the OB decomposition that contributed to explaining the gap in 2007 include labor market participation at the bottom of the distribution and changes in marital status, especially at the median. Occupation and risk preferences also contributed to the gap at the $90^{\text {th }}$ percentile, though with different signs: these factors were offsetting each other at the bottom and at the top of the distribution in the mean specification.

We find that age no longer played a role in 2012 and that the role of education in explaining the gap slightly decreased over time. As was the case at the mean, the labor market experience differences began to explain the wealth gap significantly at the median in the second period, and their effect at the bottom of the distribution increased.

The returns to changes in the marital status are significant throughout the distribution and contribute to an increase of the gap. Returns to education, instead, contribute significantly to the reduction of the gap. The returns to labor market variables contribute to the reduction of the gap only at the top of the distribution in a consistent manner over time. Thus, high wealth women have favorable returns in the labor market compared to men. Additionally, the returns 
to labor market variables become significant at the $25^{\text {th }}$ percentile indicating that in 2012 low wealth women now have an advantage over men.

Differences in occupational status consistently and significantly contribute to the gender wealth gap at the top of the distribution. The returns have a statistically significant negative effect at the $25^{\text {th }}$ percentile, especially in 2012 , once again confirming the importance of changes in the labor market to reduce the wealth gap, particularly at the bottom of the wealth distribution. As in Sierminska et al. (2010), differences in permanent income play a sizeable role, with a decreasing effect along the wealth distribution; this role diminishes in the second period, when the gap decreased.

Risk preference differences matter at the top of distribution and are significant in both periods.

The detailed decomposition point us to the increasing role of labor market variables and choice of occupations particularly at the bottom and in the middle (not at the top)s also noted at the top of the distribution that was hidden at the mean.

\section{Limitations, discussion and extensions}

One limitation of our results is related to the underrepresentation of multi-millionaires and billionaires in SOEP (Westermeier and Grabka, 2015). The fact that there are very few women among the top 1,000 riches persons in Germany, as argued by the rich list of the German Manager-Magazin (Neßhöver, 2017), indicates that our estimates of the wealth gap can be treated as a lower bound of the real gap at the top. Examining the wealth gap for the top $1 \%$ or $5 \%$ would most likely lead us to conclude the existence of substantial wealth gap in that part of the distribution due to the glass-ceiling, among other factors.

A second limitation is that among married couples and couples more generally, we do not have a perfect measure for power within couples, which could explain better the imbalances 
within couples. As well as, special agreements couples may have agreed to may explain these imbalances. This is left for future work.

We also mention a technical limitation: our measure of wealth is net worth. This concept does not include pension entitlements from statutory or occupational pension schemes (as is the case for the majority of wealth surveys like the HFCS). However, pension entitlements from pay-as-you-go pension schemes do not fulfill typical wealth functions: pension entitlements do not generate additional income like interest or dividends; they cannot be used as collateral, and cannot be fully passed over to third party and cannot be liquefied. Thus, there is no special power arising from pension entitlements. Still, one might expect that the gender wealth gap will increase if this wealth component would be considered, due to the still existent significant labor market differences between the sexes; also, probably the decrease of the gap over time would be more marked, thanks to the positive effect of female entrance into the labor market not only on immediate income, but also on future pension.

\section{Conclusions}

In this paper we investigate the way wealth accumulation has changed for women and men over the past decade. Germany had a relatively strong, albeit short recession in terms of GDP and experienced substantial changes in the labor market. Women profited significantly from the labor market changes and increased their participation in the work force by over $10 \mathrm{ppt}$ during the 2000's. We show how each of these in turn contributes to the change in wealth accumulation and whether we can observe any changes in the way wealth has been accumulated over time in Germany.

We add to the existing literature and find that the gender wealth gap for the working-age population - as measured by net worth - has declined from about 35,500 Euros (2002) to 30,700 Euros (2012). This is mostly due to a stronger decline in real net worth for men compared to women. 
When we decompose the gender wealth gap over time, we find a declining role of differences in characteristics in explaining the gap, and a smaller role of differences in returns to these characteristics (the unexplained part). This suggests that both differences in characteristics and in returns have diminished; thus, there seems to be a move toward a more equal wealth accumulation in terms of characteristics and returns. In our decompositions, we find an increasing role of labor market variables (full-time and part-time employment, unemployment) and a decreasing role of permanent income. The return to occupations that women are attracted to has an increasing, negative effect on the wealth gap over time. The role of differences in changes in marital status (and their returns) exhibit a stable role in explaining the gender wealth gap over time.

Our regression results indicate that the role of labor market covariates has increased, particularly for women in the accumulation of wealth and particularly at the bottom and in the middle of the distribution. This is related to previously not emplyed women entering the work force, as well as those working part-time moving to full-time employment. This most likely refers to low-paying jobs the type of which increased sinec the Hartz reforms. The type of occupation that is selected also plays a significant and important role in the wealth gap. Consequently, permanent income has an increasing effect on female wealth accumulation, which was absent in the first period. In terms of policy, the wealth creation capabilities could be improved if the wage gap were smaller (now at 20\%) or if women entered higher paying jobs. Thus, the currently observed changes are only a start when it comes to more equal wealth accumulation. In parallel, the male breadwinner model is becoming less popular in Germany and is accompanied by greater polarization in the marriage market. On the one hand, we observe short marriages ending in divorce and on the other lengthy marriages. The decreasing popularity of marriage accompanied by high divorce rates has shown cohabitation to be the new norm among the younger cohort. Thus, a steady inflow of women into the labor force and 
their increased capacity to build wealth is not only desirable for their increased well-being, but is a necessity, as well.

Further research could envision expanding our measure of permanent income, which at the moment takes into account the last 5 years, and develop a measure of life-time permanent income in order to provide additional insights into the role of labor market variables on the evolving gender wealth gap. Subsequently, a focus on younger age cohorts would allow us to better conclude whether the increasing trend for women to achieve higher educational levels compared to their male counterparts yields a declining wealth gap or whether the still existing gender pay gap overlays this general development. 


\section{References}

Addo, F.R. and Lichter, D.T. (2013). Marriage, marital history, and black - white wealth differentials among older women. Journal of Marriage and Family, 75, 342-362.

Alesina, A.F., Lotti, F. and Mistrulli, P.E. (2013). Do women pay more for credit? Evidence from Italy. Journal of the European Economic Association, 11(S1), 45-66.

Almenberg, J. and Dreber, A. (2015). Gender, stock market participation and financial literacy. Economics Letters, 137,140-142.

Austen, S., Jefferson, T. and Ong, R. (2014). The Gender Gap in Financial Security: What We Know and Don't Know about Australian Households. Feminist Economics, 20(3), 25-52.

Bajtelsmit, V. and Bernasek, A. (1996). Why do women invest differently than men? Financial Counselling and Planning, 7, 1-10.

Bauer, T.K., Cobb-Clark, D., Hildebrand, V. and Sinning, M.G. (2011). A comparative analysis of the nativity wealth gap. Economic Inquiry, 49(4), 989-1007.

Blinder, A.S. (1973). Wage discrimination reduced form and structural estimates. Journal of Human Resources, 8(4), 436-455.

Brenke, K. (2015). Wachsende Bedeutung der Frauen auf dem Arbeitsmarkt. DIW Wochenbericht Nr. 5-2015, S. 75-86.

Burda, M.C. and J. Hunt, J. (2011). "What Explains Germany's Labor Market Miracle in the Great Recession?” Brookings Papers on Economic Activity 421 (Spring 2011), 273-335.

Cartwright, E. (2011). Behavioral economics. Routledge, New York.

Chang, M.L. (2010). Shortchanged: Why Women Have Less Wealth and What Can be Done About It. Oxford University Press, Oxford.

Deere, C.D. and Doss, C.R. (2006). The gender asset gap: What do we know and why does it matter? Feminist Economics, 12(1-2), 1-50.

DiNardo, J., Fortin, N.M. and Lemieux, T. (1996). Labor Market Institutions and the Distribution of Wages, 1973-1992: A Semiparametric Approach, Econometrica, 64(5), 1001-1044.

Dustmann, C., Fitzenberger, B. Schönberg, U., and Spitz-Oener, A. (2014). From Sick Man of Europe to Economic Superstar: Germany's Resurgent Economy. Journal of Economic Perspectives, 28(1), 167-188.

Edlund, L. and Kopczuk, W. (2009). Women, wealth and mobility. American Economic Review, 99(1), 146-78.

Eurostat (2018). Real GDP growth rate - volume. http://appsso.eurostat.ec.europa.eu/nui/show.do? dataset $=$ tec00115\&lang=en.

Eurostat (2015). Life expectancy at birth, by sex. http://ec.europa.eu/eurostat/tgm/table.do?tab=table\&init $=1 \&$ language $=$ en $\& p c o d e=t p s 000$ 25\&plugin $=1$.

Federal Statistical Office (2018a). Gender Pay Gap. https://www.destatis.de/DE/ZahlenFakten/GesamtwirtschaftUmwelt/VerdiensteArbeitsk osten/VerdiensteVerdienstunterschiede/Tabellen/UGPG_01_Gebietsstand.html

Federal Statistical Office (2018b). Vermögen, Schulden. Einkommens- und Verbrauchsstichprobe (EVS). Geld- und Immobilienvermögen sowie Schulden privater Haushalte am 1.1. in den Gebietsständen. 
https://www.destatis.de/DE/ZahlenFakten/GesellschaftStaat/EinkommenKonsumLebens bedingungen/VermoegenSchulden/Tabellen/GeldImmobVermSchulden_EVS.html

Firpo, S., Fortin, N.M. and Lemieux, T. (2009). Unconditional Quantile Regressions. Econometrica, 77(3): 953-973.

Fisher, P.J. (2010). Gender differences in personal saving behaviors. Journal of Financial Counseling and Planning Education, 21(1), 14-24.

Fortin, N., Lemieux, T., Firpo, S. (2011). Chapter 1 - Decomposition Methods in Economics, in Orley Ashenfelter, O., and David Card, D. (eds.): Handbook of Labor Economics, Elsevier, Volume 4, Part A, Pages 1-102.

Frick, J.R., Grabka, M.M. and Sierminska, E.M. (2007). Representative wealth data for Germany from the German SOEP: The Impact of methodological decisions around imputation and the choice of the aggregation unit. DIW Discussion Paper No. 562, Berlin, March.

Goebel, J., Grabka, M.M., Liebig, S., Kroh, M., Richter, D., Schröder, C. and Schupp, J. (2019): The German Socio-Economic Panel (SOEP). Journal of Economics and Statistics, 239(2): 345-360.

Grabka, M.M and Westermeier, C. (2015). Asset Development in Germany, DIW Economic Bulletin No.34, Berlin

Grabka, M.M. (2015). Income and Wealth inequality after the financial crisis-the case of Germany. Empirica. Journal of European Economics, 42(2): 371-390

Grabka, M.M., and Westermeier, C. (2016). Editing and multiple imputation of item nonresponse in the wealth module of the German Socio-Economic Panel. SOEP Survey Papers, No. 272.

Grabka, M.M., Marcus, J. and Sierminska, E. (2015). Wealth distribution within couples. Review of Economics of the Household, 13(3), 459-486.

Huston, S.J. (2010). Measuring Financial Literacy. The Journal of Consumer Affairs, 44(2), 296-316.

Jarvis, S. and Jenkis, S.P. (1999). Marital splits and income changes: Evidence from the British Household Panel Survey. Population Studies, 3(2): 237-254.

Jianakopolos, N.A. and Bernasek, A. (1998). Are women more risk averse? Economic Inquiry, 36, 620-630.

Lersch, P.M. (2017a). The Marriage Wealth Premium Revisited: Gender Disparities and Within-Individual Changes in Personal Wealth in Germany. Demography, 54(3), 961983.

Lersch, P.M. (2017b). Individual Wealth and Subjective Financial Well-being in Marriage: Resource Integration or Separation? Journal of Marriage and Family, 79(5), 1211-1223.

Lersch, P.M., Jacob, M. and Hank, K. (2017). Parenthood, Gender, and Personal Wealth. European Sociological Review, 33(3), 410-422.

Lusardi, A., and Mitchell, O. S. (2008). Planning and financial literacy: How do women fare? American Economic Review: Papers \& Proceedings, 98(2), 413-417.

Mathae, T.Y., Porpiglia, A. and Sierminska, E. (2011). The immigrant/native wealth gap in Germany, Italy and Luxembourg, ECB Working Paper, No. 1032.

Neßhöver, C. (2017). Von Albrecht bis Würth Wie die zehn reichsten Deutschen ihr Vermögen mehren, Manager-Magazin, SH 2017. 
Oaxaca, R.L. (1973). Male-Female Wage Differentials in Urban Labor Markets. International Economic Review, 14(3): 693-709.

OECD (2012). Closing the Gender Gap: Act Now, OECD Publishing. http://dx.doi.org/10.1787/9789264179370-en

Pence, K.M. (2006). The Role of Wealth Transformations: An Application to Estimating the Effect of Tax Incentives on Saving. Contributions to Economic Analysis \& Policy, 5(1), Article 20.

Rossi, M. and Sierminska, E. (2018). Wealth and homeownership. Women, Men and Families. Palgrave Macmillan Publishing, London, (forthcoming).

Rotino, S. (2015): Der gesetzliche Güterstand im europäischen Vergleich. Arbeitspapier für die Sachverständigenkommission zum Zweiten Gleichstellungsbericht der Bundesregierung. Berlin.

Ruel, E. and Hauser, R.M. (2013). Explaining the Gender Wealth Gap. Demography, 50(4), $1155-1176$.

Schmidt, L. and Sevak, P. (2006). Gender, marriage and asset accumulation in the United States. Feminist Economics, 12 (1-2), 139-166.

Sierminska, E.M., Frick, J.R. and Grabka, M.M. (2010). Examining the gender wealth gap. Oxford Economic Papers, 62(4): 669-690.

Steiner, V., Wrohlich, K. (2004): Household Taxation, Income Splitting and Labor Supply: A Microsimulation Study for Germany, in: CESifo Economic Studies 50, Nr. 3, 541-568.

Sundén, A.E., and Surette, B.J. (1998). Gender Differences in the Allocation of Assets in Retirement Savings Plans. The American Economic Review, 88(2), 207-211.

UNECE (2014). Statistical Database. Fertility, families and households. http://w3.unece.org/pxweb/database/STAT/30-GE/02-Families households/?lang=1

US Census Bureau (2014). America's Families and Living Arrangements: 2014: Family groups. http://www.census.gov/hhes/families/data/cps2014FG.html

Vespa J., Painter M.A. (2011). Cohabitation history, marriage, and wealth accumulation, Demography 48(3): 983-1004.

Warren, T. (2006). Moving beyond the gender wealth gap: On gender, class, ethnicity, and wealth inequalities in the United Kingdom. Feminist Economics, 12(1-2), 195-219.

Warren, T., Rowlingson, K. and Whyley, C. (2001). Female finances: Gender Wage Gaps and Gender Assets Gaps. Work, Employment and Society, 15: 465-488.

Westermeier, C. and Grabka, M.M. (2015). Significant Statistical Uncertainty over Share of High Net Worth Households. Economic bulletin, no. 14+15, p. 210-219.

Yamokoski, A. and Keister, L.A. (2006). The wealth of single women: Marital status and parenthood in the asset accumulation of young baby boomers in the United States. Feminist Economics, 12(1-2), 167-194.

Xiao, J. J. (1995). Patterns of household financial asset ownership. Financial Counseling and Planning, 6, 99-106.

Zagorsky, J.L. (2005). Marriage and divorce impact on wealth. Journal of Sociology, 41(4): 406-424. 


\section{TABLES}

Table 1. Mean and median wealth over time, by gender, and gender gap. Cross-sectional sample, population aged 25-64 (2010 Euros)

\begin{tabular}{lrrr}
\hline & & Mean & Median \\
\hline Men & 2002 & 112,516 & 31,643 \\
Men & 2007 & 102,678 & 24,974 \\
Men & 2012 & 93,617 & 24,976 \\
\hline Women & 2002 & 77,030 & 18,059 \\
Women & 2007 & 69,393 & 15,088 \\
Women & 2012 & 62,902 & 14,409 \\
\hline Gender gap & 2002 & 35,487 & 13,585 \\
Gender gap & 2007 & 33,284 & 9,886 \\
Gender gap & 2012 & 30,715 & 10,567 \\
\hline
\end{tabular}

Source: SOEPv30, individuals aged 25-64.

Note: Cross-sectional weights are used. 
Table 2. Descriptive statistics, overall population aged 25-64

\begin{tabular}{|c|c|c|c|c|}
\hline Variables & Men 2007 & Men 2012 & Women 2007 & Women 2012 \\
\hline Wealth & $101,217.21$ & $97,780.90$ & $71,617.98$ & $57,831.75$ \\
\hline IHS wealth & 7.79 & 7.61 & 7.26 & 6.87 \\
\hline Migrant & 0.15 & 0.15 & 0.17 & 0.18 \\
\hline Age & 45.44 & 45.37 & 44.67 & 44.83 \\
\hline Number of children & 0.10 & 0.09 & 0.12 & 0.11 \\
\hline Lagged low educated & 0.13 & 0.11 & 0.14 & 0.11 \\
\hline Lagged lower vocational educ. & 0.52 & 0.51 & 0.54 & 0.53 \\
\hline Lagged upper vocational educ. & 0.15 & 0.15 & 0.14 & 0.15 \\
\hline Lagged university degree & 0.18 & 0.20 & 0.15 & 0.17 \\
\hline East Germany & 0.20 & 0.20 & 0.18 & 0.19 \\
\hline Full-time employment (months) ${ }^{a}$ & 47.40 & 47.88 & 20.98 & 24.98 \\
\hline Part-time employment (months) ${ }^{\mathrm{a}}$ & 2.16 & 1.80 & 16.37 & 14.18 \\
\hline Long-term unemployment ${ }^{\mathrm{a}}$ & 0.17 & 0.13 & 0.16 & 0.12 \\
\hline Lagged not employed & 0.02 & 0.01 & 0.20 & 0.14 \\
\hline Lagged trainee & 0.06 & 0.05 & 0.05 & 0.06 \\
\hline Lagged self employed & 0.09 & 0.10 & 0.04 & 0.04 \\
\hline Lagged white collar & 0.34 & 0.33 & 0.43 & 0.49 \\
\hline Lagged blue collar & 0.36 & 0.36 & 0.17 & 0.14 \\
\hline Lagged low civil servants & 0.03 & 0.03 & 0.01 & 0.02 \\
\hline Lagged high civil servants & 0.04 & 0.04 & 0.02 & 0.02 \\
\hline Permanent income ${ }^{\mathrm{a}}$ & $34,329.79$ & $34,082.86$ & $16,565.16$ & $18,210.13$ \\
\hline Always married & 0.53 & 0.48 & 0.55 & 0.49 \\
\hline Married to widowed & 0.00 & 0.00 & 0.01 & 0.01 \\
\hline Married to divorced/separated & 0.04 & 0.04 & 0.04 & 0.03 \\
\hline Never married to married & 0.05 & 0.05 & 0.05 & 0.05 \\
\hline Always never married & 0.25 & 0.30 & 0.18 & 0.23 \\
\hline Single to married & 0.03 & 0.03 & 0.03 & 0.04 \\
\hline Single (other) & 0.10 & 0.09 & 0.14 & 0.15 \\
\hline Number of marriages ${ }^{b}$ & 1.19 & 1.18 & 1.21 & 1.23 \\
\hline Length of marriage ${ }^{b}$ & 15.94 & 15.17 & 15.97 & 14.71 \\
\hline Lagged risk preferences & 5.01 & 5.03 & 4.24 & 4.21 \\
\hline $\mathrm{HH}$ Value inherit./bestowal/lottery ${ }^{\mathrm{c}}$ & $46,536.89$ & $28,428.29$ & $52,948.96$ & $54,455.94$ \\
\hline Financial assets share & 0.20 & 0.20 & 0.28 & 0.35 \\
\hline Hold own property & 0.33 & 0.32 & 0.29 & 0.27 \\
\hline Sell own property & 0.03 & 0.03 & 0.04 & 0.04 \\
\hline Buy own property & 0.09 & 0.09 & 0.10 & 0.09 \\
\hline Always tenant & 0.55 & 0.57 & 0.57 & 0.61 \\
\hline Hold consumer debts & 0.10 & 0.13 & 0.06 & 0.13 \\
\hline No more consumer debts & 0.09 & 0.11 & 0.08 & 0.09 \\
\hline Acquire consumer debts & 0.15 & 0.12 & 0.13 & 0.10 \\
\hline No consumer debts & 0.66 & 0.63 & 0.73 & 0.68 \\
\hline Lagged tangible assets & 0.09 & 0.08 & 0.08 & 0.05 \\
\hline Lagged property debts & 0.25 & 0.25 & 0.23 & 0.21 \\
\hline HH Hold stocks & 0.22 & 0.22 & 0.21 & 0.21 \\
\hline HH Sell stocks & 0.12 & 0.11 & 0.13 & 0.11 \\
\hline HH Buy stocks & 0.09 & 0.06 & 0.09 & 0.08 \\
\hline HH No stocks & 0.56 & 0.61 & 0.57 & 0.61 \\
\hline HH Inheritances/bestowals & 0.12 & 0.16 & 0.12 & 0.15 \\
\hline HH Lottery & 0.01 & 0.01 & 0.01 & 0.02 \\
\hline HH Savings & 0.82 & 0.82 & 0.80 & 0.81 \\
\hline Lagged worried for financial reasons & 1.99 & 2.06 & 2.01 & 2.09 \\
\hline Observations & 5,240 & 3,813 & 5,824 & 4,388 \\
\hline Weighted obs. & 4,922 & 3,591 & 5,504 & 4,151 \\
\hline
\end{tabular}

Source: SOEPv30, individuals aged 25-64. Panel samples 2002-2007 and 2007-2012 are used.

Note: ${ }^{\mathrm{a}}$ It refers to the previous 5 years (e.g. 2002-2007; 2002-2012). ${ }^{\mathrm{b}}$ It refers to those who have been married at least once (i.e. excluding never married) (obs: $3958,2798,4678,3460) .{ }^{\mathrm{c}}$ Here shown the value only for people with positive inheritances/gifts/lottery (obs: $699 ; 602 ; 797 ; 704$ ) - for all the others the value is 0 . IHS stands for "inverse hyperbolic sine" transformation; HH stands for household. 
Table 3. Portfolio composition: Percentage of people who have the following assets. Overall population aged $25-64$

\begin{tabular}{lrrrr}
\hline Variables & Men & Men & Women & Women \\
& 2007 & 2012 & 2007 & 2012 \\
\hline Own property & 0.42 & 0.40 & 0.39 & 0.36 \\
Other real estate & 0.12 & 0.13 & 0.10 & 0.09 \\
Financial assets & 0.49 & 0.48 & 0.44 & 0.43 \\
Business assets & 0.08 & 0.09 & 0.03 & 0.03 \\
Tangible assets & 0.06 & 0.08 & 0.06 & 0.07 \\
Building loan and Private insurances & 0.69 & 0.68 & 0.61 & 0.60 \\
Consumer credits & 0.24 & 0.26 & 0.19 & 0.22 \\
Property debts & 0.65 & 0.63 & 0.65 & 0.62 \\
Other real estate debts $*$ & 0.52 & 0.53 & 0.45 & 0.55 \\
\hline
\end{tabular}

Source: SOEPv30, individuals aged 25-64. Panel samples 2002-2007 and 2007-2012 are used Note: * Conditional on having that type of property. 
Table 4. Determinants of wealth for overall population aged 25-64, by gender

\begin{tabular}{|c|c|c|c|c|}
\hline$y=I H S$ wealth & Men 2007 & Men 2012 & Women 2007 & Women 2012 \\
\hline Migrant & $\begin{array}{c}-1.95 * * * \\
(0.26)\end{array}$ & $\begin{array}{c}-1.49 * * * \\
(0.31)\end{array}$ & $\begin{array}{l}-1.90 * * * \\
(0.24)\end{array}$ & $\begin{array}{l}-1.27 * * * \\
(0.28)\end{array}$ \\
\hline Age & $\begin{array}{l}0.08 \\
(0.09)\end{array}$ & $\begin{array}{c}-0.04 \\
(0.10)\end{array}$ & $\begin{array}{l}0.14+ \\
(0.08)\end{array}$ & $\begin{array}{l}0.18+ \\
(0.09)\end{array}$ \\
\hline Age squared & $\begin{array}{l}0.00 \\
(0.00)\end{array}$ & $\begin{array}{l}0.00 \\
(0.00)\end{array}$ & $\begin{array}{c}-0.00 \\
(0.00)\end{array}$ & $\begin{array}{c}-0.00 \\
(0.00)\end{array}$ \\
\hline Number of children & $\begin{array}{c}-0.16 \\
(0.27)\end{array}$ & $\begin{array}{c}-0.11 \\
(0.32)\end{array}$ & $\begin{array}{c}-0.13 \\
(0.25)\end{array}$ & $\begin{array}{c}-0.76^{*} \\
(0.30)\end{array}$ \\
\hline Lagged lower voc. education & $\begin{array}{l}0.53+ \\
(0.29)\end{array}$ & $\begin{array}{l}1.38 * * * \\
(0.36)\end{array}$ & $\begin{array}{l}1.50 * * * \\
(0.25)\end{array}$ & $\begin{array}{l}1.08 * * * \\
(0.31)\end{array}$ \\
\hline Lagged upper voc. education & $\begin{array}{l}0.91 * \\
(0.35)\end{array}$ & $\begin{array}{l}2.04 * * * \\
(0.43)\end{array}$ & $\begin{array}{l}1.98 * * * \\
(0.31)\end{array}$ & $\begin{array}{l}1.68 * * * \\
(0.38)\end{array}$ \\
\hline Lagged university degree & $\begin{array}{l}1.38 * * * \\
(0.35)\end{array}$ & $\begin{array}{l}2.54 * * * \\
(0.42)\end{array}$ & $\begin{array}{l}2.61 * * * \\
(0.31)\end{array}$ & $\begin{array}{l}2.63 * * * \\
(0.37)\end{array}$ \\
\hline East Germany & $\begin{array}{l}-0.72 * * \\
(0.22)\end{array}$ & $\begin{array}{l}-1.12 * * * \\
(0.24)\end{array}$ & $\begin{array}{l}-0.90 * * * \\
(0.21)\end{array}$ & $\begin{array}{l}-0.98 * * * \\
(0.23)\end{array}$ \\
\hline Full time employment (months) & $\begin{array}{l}0.03 * * * \\
(0.01)\end{array}$ & $\begin{array}{l}0.02 * \\
(0.01)\end{array}$ & $\begin{array}{l}0.01 * \\
(0.01)\end{array}$ & $\begin{array}{c}-0.00 \\
(0.01)\end{array}$ \\
\hline Part time employment (months) & $\begin{array}{l}0.01 \\
(0.01)\end{array}$ & $\begin{array}{c}-0.01 \\
(0.01)\end{array}$ & $\begin{array}{l}0.01 \\
(0.01)\end{array}$ & $\begin{array}{l}0.01 * \\
(0.01)\end{array}$ \\
\hline Long term unemployment & $\begin{array}{l}-2.50 * * * \\
(0.34)\end{array}$ & $\begin{array}{c}-2.89 * * * \\
(0.43)\end{array}$ & $\begin{array}{l}-2.72 * * * \\
(0.28)\end{array}$ & $\begin{array}{c}-2.03 * * * \\
(0.34)\end{array}$ \\
\hline Lagged Not employed & $\begin{array}{l}1.28 \\
(0.82)\end{array}$ & $\begin{array}{l}0.84 \\
(0.87)\end{array}$ & $\begin{array}{l}0.43 \\
(0.32)\end{array}$ & $\begin{array}{l}1.83 * * * \\
(0.37)\end{array}$ \\
\hline Lagged Trainee & $\begin{array}{l}0.49 \\
(0.47)\end{array}$ & $\begin{array}{l}0.10 \\
(0.57)\end{array}$ & $\begin{array}{l}0.97^{*} \\
(0.43)\end{array}$ & $\begin{array}{l}2.34 * * * \\
(0.54)\end{array}$ \\
\hline Lagged Self-employed & $\begin{array}{l}1.29 * * * \\
(0.33)\end{array}$ & $\begin{array}{l}1.65 * * * \\
(0.38)\end{array}$ & $\begin{array}{l}1.12 * * \\
(0.41)\end{array}$ & $\begin{array}{l}1.89 * * * \\
(0.45)\end{array}$ \\
\hline Lagged White collar & $\begin{array}{l}0.91 * * * \\
(0.24)\end{array}$ & $\begin{array}{l}0.95 * * * \\
(0.27)\end{array}$ & $\begin{array}{l}1.09 * * * \\
(0.24)\end{array}$ & $\begin{array}{l}2.04 * * * \\
(0.27)\end{array}$ \\
\hline Lagged Low civil servants & $\begin{array}{l}0.75 \\
(0.57)\end{array}$ & $\begin{array}{l}2.57 * * * \\
(0.69)\end{array}$ & $\begin{array}{l}2.20 * * \\
(0.80)\end{array}$ & $\begin{array}{l}2.97 * * * \\
(0.86)\end{array}$ \\
\hline Lagged High civil servants & $\begin{array}{l}0.24 \\
(0.45)\end{array}$ & $\begin{array}{l}0.99^{*} \\
(0.50)\end{array}$ & $\begin{array}{l}1.40 * * \\
(0.49)\end{array}$ & $\begin{array}{l}1.43^{* *} \\
(0.55)\end{array}$ \\
\hline IHS permanent income & $\begin{array}{l}0.78 * * * \\
(0.12)\end{array}$ & $\begin{array}{l}0.31 * * * \\
(0.09)\end{array}$ & $\begin{array}{l}0.00 \\
(0.04)\end{array}$ & $\begin{array}{l}0.13 * \\
(0.05)\end{array}$ \\
\hline Married to widowed & $\begin{array}{l}1.41 \\
(1.81)\end{array}$ & $\begin{array}{l}3.09 \\
(1.98)\end{array}$ & $\begin{array}{l}0.64 \\
(0.92)\end{array}$ & $\begin{array}{c}-1.75+ \\
(0.99)\end{array}$ \\
\hline Married to divorced/separated & $\begin{array}{l}-2.35 * * * \\
(0.51)\end{array}$ & $\begin{array}{l}-2.26 * * * \\
(0.63)\end{array}$ & $\begin{array}{l}-2.65 * * * \\
(0.45)\end{array}$ & $\begin{array}{l}-2.32 * * * \\
(0.57)\end{array}$ \\
\hline Never married to married & $\begin{array}{c}-0.47 \\
(0.49)\end{array}$ & $\begin{array}{c}-0.06 \\
(0.57)\end{array}$ & $\begin{array}{c}-0.86+ \\
(0.48)\end{array}$ & $\begin{array}{l}0.34 \\
(0.55)\end{array}$ \\
\hline Always never married & $\begin{array}{c}-2.01 * * * \\
(0.50)\end{array}$ & $\begin{array}{c}-1.66^{* *} \\
(0.57)\end{array}$ & $\begin{array}{c}-2.47 * * * \\
(0.47)\end{array}$ & $\begin{array}{c}-2.77 * * * \\
(0.52)\end{array}$ \\
\hline Single to married & $\begin{array}{c}-0.00 \\
(0.56)\end{array}$ & $\begin{array}{c}-1.15+ \\
(0.64)\end{array}$ & $\begin{array}{c}-1.54 * * \\
(0.53)\end{array}$ & $\begin{array}{c}-0.43 \\
(0.58)\end{array}$ \\
\hline Single (other) & $\begin{array}{c}-1.93 * * * \\
(0.43)\end{array}$ & $\begin{array}{c}-1.36^{* *} \\
(0.50)\end{array}$ & $\begin{array}{l}-2.22 * * * \\
(0.38)\end{array}$ & $\begin{array}{c}-2.49 * * * \\
(0.43)\end{array}$ \\
\hline Number of marriages & $\begin{array}{c}-1.34 * * * \\
(0.23)\end{array}$ & $\begin{array}{c}-1.61 * * * \\
(0.27)\end{array}$ & $\begin{array}{c}-0.94 * * * \\
(0.20)\end{array}$ & $\begin{array}{c}-1.49 * * * \\
(0.22)\end{array}$ \\
\hline Length of marriage & $\begin{array}{l}0.01 \\
(0.01)\end{array}$ & $\begin{array}{l}0.03 \\
(0.02)\end{array}$ & $\begin{array}{l}0.00 \\
(0.01)\end{array}$ & $\begin{array}{c}-0.01 \\
(0.01)\end{array}$ \\
\hline Lagged risk preferences & $\begin{array}{c}-0.05 \\
(0.04)\end{array}$ & $\begin{array}{c}-0.06 \\
(0.05)\end{array}$ & $\begin{array}{l}0.01 \\
(0.04)\end{array}$ & $\begin{array}{c}-0.04 \\
(0.04)\end{array}$ \\
\hline HH Value inheritances/bestowal/lottery & $\begin{array}{l}0.13 * * * \\
(0.02)\end{array}$ & $\begin{array}{l}0.08 * * \\
(0.03)\end{array}$ & $\begin{array}{l}0.17 * * * \\
(0.02)\end{array}$ & $\begin{array}{l}0.09 * * * \\
(0.02)\end{array}$ \\
\hline Financial assets share & $\begin{array}{l}0.50 * * * \\
(0.10)\end{array}$ & $\begin{array}{l}0.51 * * * \\
(0.11)\end{array}$ & $\begin{array}{l}0.44 * * * \\
(0.08)\end{array}$ & $\begin{array}{l}0.46^{* * * *} \\
(0.09)\end{array}$ \\
\hline Constant & $\begin{array}{c}-4.32+ \\
(2.34) \\
\end{array}$ & $\begin{array}{l}2.99 \\
(2.48) \\
\end{array}$ & $\begin{array}{l}1.85 \\
(1.92) \\
\end{array}$ & $\begin{array}{c}-0.64 \\
(2.30) \\
\end{array}$ \\
\hline Adj. R2 & 0.21 & 0.20 & 0.19 & 0.18 \\
\hline Observations & 5,240 & 3,813 & 5,824 & 4,388 \\
\hline
\end{tabular}

Source: SOEPv30, individuals aged 25-64. Panel samples 2002-2007 and 2007-2012 are used.

Note: + p-value $<0.10 ; *$ p-value $<0.05 ; * *$ p-value $<0.01 ; * * *$ p-value $<0.001$. Standard errors in parentheses.

Controlling for missing variables. Reference categories: German, lagged low educated, West Germany, lagged blue collar, always married. HH stands for household. 
Table 5. Oaxaca-Blinder decomposition of the wealth gap, overall population aged 25-64

\begin{tabular}{|c|c|c|c|c|}
\hline \multirow{2}{*}{ Overall gap decomposition } & \multicolumn{2}{|c|}{2007} & \multicolumn{2}{|c|}{2012} \\
\hline & Means & SE & Means & SE \\
\hline Men & $8.449 * * *$ & 0.096 & $8.490 * * *$ & 0.111 \\
\hline Women & $7.969 * * *$ & 0.088 & $7.974 * * *$ & 0.101 \\
\hline Difference & $0.479 * * *$ & 0.130 & $0.517 * * *$ & 0.150 \\
\hline Explained & $1.580 * * *$ & 0.250 & $1.043 * * *$ & 0.239 \\
\hline Unexplained & $-1.101 * * *$ & 0.269 & $-0.526^{*}$ & 0.267 \\
\hline \multicolumn{5}{|l|}{ Explained gap } \\
\hline Migration & 0.005 & 0.014 & 0.013 & 0.012 \\
\hline Age & $0.055 * *$ & 0.021 & 0.023 & 0.022 \\
\hline Kids & 0.001 & 0.002 & 0.000 & 0.001 \\
\hline Education & $0.051 * * *$ & 0.015 & $0.049 * *$ & 0.019 \\
\hline Residence & -0.007 & 0.006 & -0.006 & 0.011 \\
\hline Labor market participation & 0.364 & 0.245 & $0.615 * *$ & 0.229 \\
\hline Occupation & -0.016 & 0.024 & -0.000 & 0.031 \\
\hline Income & $1.138 * * *$ & 0.171 & $0.351 * * *$ & 0.100 \\
\hline Marital status & -0.035 & 0.030 & -0.054 & 0.037 \\
\hline Other marital variables & $0.085 * *$ & 0.030 & $0.121 * *$ & 0.039 \\
\hline Risk preferences & -0.040 & 0.035 & -0.052 & 0.041 \\
\hline HH Value inherit./bestowal/lottery & -0.006 & 0.009 & -0.002 & 0.007 \\
\hline Financial assets share & $-0.016+$ & 0.010 & -0.013 & 0.011 \\
\hline Other (missing) & 0.001 & 0.005 & -0.002 & 0.006 \\
\hline \multicolumn{5}{|l|}{ Unexplained gap } \\
\hline Migration & -0.008 & 0.056 & -0.031 & 0.057 \\
\hline Age & -1.340 & 2.643 & $-5.932+$ & 3.080 \\
\hline Kids & -0.003 & 0.044 & 0.068 & 0.046 \\
\hline Education & $-0.885 * *$ & 0.312 & 0.180 & 0.405 \\
\hline Residence & 0.043 & 0.071 & -0.034 & 0.084 \\
\hline Labor market participation & 0.468 & 0.503 & -0.101 & 0.515 \\
\hline Occupation & -0.162 & 0.194 & $-0.677 * *$ & 0.238 \\
\hline Income & $7.427 * * *$ & 1.173 & $1.771+$ & 0.981 \\
\hline Marital status & 0.181 & 0.182 & 0.352 & 0.230 \\
\hline Other marital variables & -0.364 & 0.492 & 0.335 & 0.547 \\
\hline Risk preferences & -0.247 & 0.231 & -0.094 & 0.260 \\
\hline HH Value inherit./bestowal/lottery & -0.058 & 0.048 & -0.008 & 0.060 \\
\hline Financial assets share & 0.013 & 0.029 & 0.012 & 0.032 \\
\hline Other (missing) & 0.005 & 0.026 & 0.008 & 0.028 \\
\hline Constant & $-6.172 *$ & 3.026 & 3.625 & 3.382 \\
\hline
\end{tabular}

Source: SOEPv30, individuals aged 25-64. Panel samples 2002-2007 and 2007-2012 are used.

Note: $+p<0.1 ; * p<0.05 ; * * p<0.01 ; * * * p<0.001$. Controlling for all the variables listed in Table 4 .

Labour market participation include full time, part-time, unemployment, not employed. For the variables included in the other groups, see the Appendix B; HH stands for household. 
Table 6. Firpo decomposition, overall population aged 25-64

\begin{tabular}{|c|c|c|c|c|c|c|}
\hline \multirow[b]{2}{*}{ Overall gap decomp. } & \multicolumn{3}{|c|}{2007} & \multicolumn{3}{|c|}{2012} \\
\hline & Q25 & Q50 & Q90 & Q25 & Q50 & Q90 \\
\hline Men & $8.941 * * *$ & $11.375 * * *$ & $13.326 * * *$ & $8.954 * * *$ & $11.425 * * *$ & $13.257 * * *$ \\
\hline Women & $7.489 * * *$ & $10.947 * * *$ & $12.998 * * *$ & $8.430 * * *$ & $10.956 * * *$ & $12.948 * * *$ \\
\hline Difference & $1.452 * * *$ & $0.428 * * *$ & $0.328 * * *$ & 0.523 & $0.468 * * *$ & $0.309 * * *$ \\
\hline Explained & $3.058 * * *$ & $0.619 * * *$ & $0.501 * * *$ & $2.026 * * *$ & $0.576 * * *$ & $0.381 * * *$ \\
\hline Unexplained & $-1.606 * *$ & -0.191 & $-0.173 *$ & $-1.502+$ & -0.107 & -0.072 \\
\hline \multicolumn{7}{|l|}{ Explained gap } \\
\hline Migration & 0.010 & 0.002 & 0.001 & 0.022 & 0.005 & 0.003 \\
\hline Age & $0.083 *$ & $0.029 *$ & $0.016^{*}$ & 0.024 & 0.015 & 0.006 \\
\hline Kids & 0.001 & 0.000 & 0.000 & -0.001 & 0.000 & 0.000 \\
\hline Education & $0.091 * * *$ & $0.028 * * *$ & $0.017 * * *$ & $0.079 *$ & $0.022 *$ & $0.013 *$ \\
\hline Residence & -0.007 & -0.006 & -0.005 & -0.007 & -0.004 & -0.004 \\
\hline Labor market part. & $1.150 * *$ & -0.113 & -0.108 & $1.263 * * *$ & $0.281 *$ & 0.125 \\
\hline Occupation & -0.049 & 0.010 & $0.073 * * *$ & -0.005 & -0.004 & $0.060 * * *$ \\
\hline Income & $1.831 * * *$ & $0.666^{* * *}$ & $0.464 * * *$ & $0.759 * * *$ & $0.259 * * *$ & $0.148 * * *$ \\
\hline Marital status & -0.037 & $-0.033^{*}$ & -0.004 & -0.071 & $-0.050 * *$ & -0.007 \\
\hline Other marital var. & $0.086+$ & 0.014 & 0.013 & $0.121 *$ & $0.051 * *$ & 0.009 \\
\hline Risk preferences & -0.059 & 0.020 & $0.033 * *$ & $-0.133 *$ & 0.007 & $0.025+$ \\
\hline HH Value inherit. & -0.009 & -0.003 & -0.002 & -0.004 & -0.001 & -0.000 \\
\hline Financial assets share & $-0.034+$ & 0.002 & 0.002 & -0.026 & -0.003 & 0.001 \\
\hline Other (missing) & 0.001 & 0.001 & 0.001 & 0.004 & -0.001 & 0.002 \\
\hline \multicolumn{7}{|l|}{ Unexplained gap } \\
\hline Migration & $0.646^{* * *}$ & 0.034 & 0.001 & $0.925 * *$ & 0.024 & 0.013 \\
\hline Age & -2.202 & 0.023 & -1.308 & $-30.629 *$ & -1.006 & 0.540 \\
\hline Kids & -0.083 & -0.008 & -0.010 & $0.376+$ & 0.009 & 0.012 \\
\hline Education & $-5.202 * * *$ & $-0.296^{*}$ & -0.110 & $-9.004 * * *$ & -0.236 & 0.051 \\
\hline Residence & 0.258 & 0.027 & 0.032 & $1.028 *$ & 0.016 & 0.004 \\
\hline Labor market part. & 0.539 & 0.077 & $-0.404 *$ & $-4.332 *$ & -0.389 & $-0.395 *$ \\
\hline Occupation & $-0.951+$ & -0.088 & -0.047 & $-8.622 * * *$ & $-0.217+$ & -0.049 \\
\hline Income & $10.110 * * *$ & $4.019 * * *$ & $3.037 * * *$ & -5.791 & $1.747 * * *$ & $1.372 * * *$ \\
\hline Marital status & $1.774 * * *$ & $0.377 * * *$ & -0.014 & $5.513 * * *$ & $0.307^{*}$ & $0.180^{*}$ \\
\hline Other marital var. & 1.436 & 0.386 & -0.046 & $8.501 * *$ & -0.018 & $0.323+$ \\
\hline Risk preferences & -0.936 & -0.071 & 0.082 & -0.449 & 0.047 & 0.134 \\
\hline HH Value inherit. & $-0.450 * * *$ & $-0.089 * * *$ & -0.017 & $-0.816^{* *}$ & -0.047 & $-0.042 *$ \\
\hline Financial assets share & $-0.191 * *$ & $-0.035^{*}$ & -0.002 & $-0.597 * * *$ & -0.014 & 0.007 \\
\hline Other (missing) & -0.006 & -0.002 & -0.011 & -0.111 & -0.011 & -0.000 \\
\hline Constant & -6.349 & $-4.545^{* *}$ & -1.357 & $42.508^{*}$ & -0.320 & $-2.223^{*}$ \\
\hline
\end{tabular}

Source: SOEPv30, individuals aged 25-64. Panel samples 2002-2007 and 2007-2012 are used.

Note: $+p<0.1 ; * p<0.05 ; * * p<0.01 ; * * * p<0.001$. Controlling for all the variables listed in Table 4 .

Labour market participation include full time, part-time, unemployment, not employed. For the variables included in the other groups, see the Appendix B; HH stands for household. 


\section{APPENDIX A}

\section{Additional Tables}

Tab. A.1 Mean and median wealth over time, by gender, and gender gap. Panel sample (2010 Euros)

\begin{tabular}{|c|c|c|c|c|c|c|c|}
\hline & & Overall & $\begin{array}{l}\quad \text { Mean } \\
\text { Married in } \\
\text { period 1 } \\
\end{array}$ & $\begin{array}{l}\text { Never married } \\
\text { in period } 1\end{array}$ & Overall & $\begin{array}{l}\quad \text { Median } \\
\text { Married in } \\
\text { period 1 } \\
\end{array}$ & $\begin{array}{l}\text { Never married } \\
\text { in period } 1\end{array}$ \\
\hline Men & 2002 & 101,677 & 120,459 & 52,746 & 28,217 & 50,790 & 7,901 \\
\hline Men & 2007 & 100,867 & 125,298 & 60,237 & 29,136 & 53,695 & 10,406 \\
\hline Women & 2002 & 73,001 & 88,116 & 41,817 & 16,930 & 30,949 & 4,740 \\
\hline Women & 2007 & 71,677 & 87,405 & 44,563 & 17,690 & 33,819 & 7,960 \\
\hline Gender Gap & 2002 & 28,676 & 32,343 & 10,929 & 11,287 & 19,841 & 3,160 \\
\hline Gender Gap & 2007 & 29,190 & 37,894 & 15,674 & 11,446 & 19,876 & 2,445 \\
\hline Men & 2007 & 98,869 & 118,433 & 71,300 & 23,413 & 41,623 & 10,406 \\
\hline Men & 2012 & 96,406 & 122,839 & 61,816 & 28,050 & 49,952 & 9,585 \\
\hline Women & 2007 & 58,599 & 73,775 & 33,816 & 13,736 & 26,327 & 5,411 \\
\hline Women & 2012 & 57,603 & 77,688 & 29,871 & 13,256 & 30,019 & 6,724 \\
\hline Gender Gap & 2007 & 40,270 & 44,658 & 37,484 & 9,677 & 15,297 & 4,995 \\
\hline Gender Gap & 2012 & 38,803 & 45,152 & 31,945 & 14,793 & 19,933 & 2,861 \\
\hline
\end{tabular}

Source: SOEPv30, individuals aged 25-64. Panel samples 2002-2007 and 2007-2012 are used.

Note: Panel weights are used. 
Table. A.2 Determinants of wealth for overall population aged 25-64, by gender. Long regressions

\begin{tabular}{|c|c|c|c|c|}
\hline$y=I H S$ wealth & Men 2007 & Men 2012 & Women 2007 & Women 2012 \\
\hline Migrant & $\begin{array}{c}-0.92 * * * \\
(0.22)\end{array}$ & $\begin{array}{c}-0.78^{* *} \\
(0.26)\end{array}$ & $\begin{array}{c}-0.76^{* * *} \\
(0.19)\end{array}$ & $\begin{array}{c}-0.44+ \\
(0.23)\end{array}$ \\
\hline Age & $\begin{array}{l}0.05 \\
(0.07)\end{array}$ & $\begin{array}{c}-0.08 \\
(0.08)\end{array}$ & $\begin{array}{l}0.10+ \\
(0.06)\end{array}$ & $\begin{array}{l}0.13+ \\
(0.08)\end{array}$ \\
\hline Age squared & $\begin{array}{l}0.00 \\
(0.00)\end{array}$ & $\begin{array}{l}0.00 \\
(0.00)\end{array}$ & $\begin{array}{c}-0.00 \\
(0.00)\end{array}$ & $\begin{array}{c}-0.00 \\
(0.00)\end{array}$ \\
\hline Number of children & $\begin{array}{c}-0.39+ \\
(0.23)\end{array}$ & $\begin{array}{c}-0.16 \\
(0.27)\end{array}$ & $\begin{array}{c}-0.62 * * \\
(0.20)\end{array}$ & $\begin{array}{c}-0.57^{*} \\
(0.24)\end{array}$ \\
\hline Lagged lower voc. Education & $\begin{array}{l}0.19 \\
(0.24)\end{array}$ & $\begin{array}{l}1.02 * * * \\
(0.30)\end{array}$ & $\begin{array}{l}0.98 * * * \\
(0.20)\end{array}$ & $\begin{array}{l}0.52 * \\
(0.25)\end{array}$ \\
\hline Lagged upper voc. Education & $\begin{array}{l}0.44 \\
(0.30)\end{array}$ & $\begin{array}{l}1.45^{* * * *} \\
(0.36)\end{array}$ & $\begin{array}{l}1.08 * * * \\
(0.24)\end{array}$ & $\begin{array}{l}0.61^{*} \\
(0.30)\end{array}$ \\
\hline Lagged university degree & $\begin{array}{l}0.28 \\
(0.29)\end{array}$ & $\begin{array}{l}1.56^{* * *} \\
(0.35)\end{array}$ & $\begin{array}{l}1.45^{* * *} \\
(0.25)\end{array}$ & $\begin{array}{l}1.34 * * * \\
(0.30)\end{array}$ \\
\hline East Germany & $\begin{array}{c}-0.20 \\
(0.19)\end{array}$ & $\begin{array}{c}-0.60 * * \\
(0.20)\end{array}$ & $\begin{array}{c}-0.13 \\
(0.17)\end{array}$ & $\begin{array}{c}-0.36+ \\
(0.19)\end{array}$ \\
\hline Full time empl. (months) & $\begin{array}{l}0.03 * * * \\
(0.01)\end{array}$ & $\begin{array}{l}0.02 * * * \\
(0.01)\end{array}$ & $\begin{array}{l}0.02 * * * \\
(0.00)\end{array}$ & $\begin{array}{l}0.01+ \\
(0.01)\end{array}$ \\
\hline Part time empl. (months) & $\begin{array}{l}0.01 \\
(0.01)\end{array}$ & $\begin{array}{l}0.00 \\
(0.01)\end{array}$ & $\begin{array}{l}0.01 \\
(0.01)\end{array}$ & $\begin{array}{l}0.01 * \\
(0.01)\end{array}$ \\
\hline Long term unemployment & $\begin{array}{l}-1.18 * * * \\
(0.29)\end{array}$ & $\begin{array}{c}-1.63 * * * \\
(0.36)\end{array}$ & $\begin{array}{c}-1.48 * * * \\
(0.23)\end{array}$ & $\begin{array}{c}-0.77 * * \\
(0.28)\end{array}$ \\
\hline Lagged Not employed & $\begin{array}{l}0.16 \\
(0.69)\end{array}$ & $\begin{array}{l}0.36 \\
(0.72)\end{array}$ & $\begin{array}{c}-0.03 \\
(0.26)\end{array}$ & $\begin{array}{l}0.86^{* *} \\
(0.30)\end{array}$ \\
\hline Lagged Trainee & $\begin{array}{c}-0.43 \\
(0.40)\end{array}$ & $\begin{array}{c}-0.11 \\
(0.48)\end{array}$ & $\begin{array}{l}0.43 \\
(0.34)\end{array}$ & $\begin{array}{l}1.37 * * \\
(0.44)\end{array}$ \\
\hline Lagged Self-employed & $\begin{array}{l}1.26 * * * \\
(0.28)\end{array}$ & $\begin{array}{l}1.64 * * * \\
(0.31)\end{array}$ & $\begin{array}{l}0.45 \\
(0.33)\end{array}$ & $\begin{array}{l}1.00 * * \\
(0.37)\end{array}$ \\
\hline Lagged White collar & $\begin{array}{l}0.25 \\
(0.20)\end{array}$ & $\begin{array}{l}0.31 \\
(0.23)\end{array}$ & $\begin{array}{l}0.39 * \\
(0.19)\end{array}$ & $\begin{array}{l}0.96 * * * \\
(0.22)\end{array}$ \\
\hline Lagged Low civil servants & $\begin{array}{r}-0.08 \\
(0.48)\end{array}$ & $\begin{array}{l}1.57^{* *} \\
(0.57)\end{array}$ & $\begin{array}{l}1.34^{*} \\
(0.63)\end{array}$ & $\begin{array}{l}1.38^{*} \\
(0.70)\end{array}$ \\
\hline Lagged High civil servants & $\begin{array}{c}-0.42 \\
(0.38)\end{array}$ & $\begin{array}{c}-0.17 \\
(0.42)\end{array}$ & $\begin{array}{c}-0.12 \\
(0.39)\end{array}$ & $\begin{array}{c}-0.13 \\
(0.45)\end{array}$ \\
\hline IHS permanent income & $\begin{array}{l}0.31^{* *} \\
(0.10)\end{array}$ & $\begin{array}{l}0.08 \\
(0.07)\end{array}$ & $\begin{array}{l}0.03 \\
(0.03)\end{array}$ & $\begin{array}{l}0.11^{* *} \\
(0.04)\end{array}$ \\
\hline Married to widowed & $\begin{array}{l}0.12 \\
(1.52)\end{array}$ & $\begin{array}{l}2.21 \\
(1.64)\end{array}$ & $\begin{array}{l}0.24 \\
(0.72)\end{array}$ & $\begin{array}{c}-0.31 \\
(0.80)\end{array}$ \\
\hline Married to divorced/separated & $\begin{array}{c}-0.72 \\
(0.44)\end{array}$ & $\begin{array}{c}-0.97+ \\
(0.53)\end{array}$ & $\begin{array}{c}-1.11 * * \\
(0.36)\end{array}$ & $\begin{array}{l}0.25 \\
(0.48)\end{array}$ \\
\hline Never married to married & $\begin{array}{l}0.20 \\
(0.42)\end{array}$ & $\begin{array}{l}0.62 \\
(0.47)\end{array}$ & $\begin{array}{l}0.28 \\
(0.38)\end{array}$ & $\begin{array}{l}1.09^{*} \\
(0.44)\end{array}$ \\
\hline Always never married & $\begin{array}{c}-0.27 \\
(0.42)\end{array}$ & $\begin{array}{c}-0.37 \\
(0.48)\end{array}$ & $\begin{array}{l}0.01 \\
(0.37)\end{array}$ & $\begin{array}{c}-0.25 \\
(0.43)\end{array}$ \\
\hline Single to married & $\begin{array}{l}0.29 \\
(0.47)\end{array}$ & $\begin{array}{c}-0.86 \\
(0.53)\end{array}$ & $\begin{array}{c}-0.47 \\
(0.42)\end{array}$ & $\begin{array}{l}0.34 \\
(0.47)\end{array}$ \\
\hline Single (other) & $\begin{array}{c}-0.58 \\
(0.36)\end{array}$ & $\begin{array}{c}-0.21 \\
(0.42)\end{array}$ & $\begin{array}{c}-0.18 \\
(0.31)\end{array}$ & $\begin{array}{c}-0.38 \\
(0.35)\end{array}$ \\
\hline Number of marriages & $\begin{array}{c}-0.41 * \\
(0.20)\end{array}$ & $\begin{array}{l}-0.82 * * * \\
(0.22)\end{array}$ & $\begin{array}{c}-0.03 \\
(0.16)\end{array}$ & $\begin{array}{c}-0.58 * * \\
(0.18)\end{array}$ \\
\hline Length of marriage & $\begin{array}{c}-0.01 \\
(0.01)\end{array}$ & $\begin{array}{l}0.01 \\
(0.01)\end{array}$ & $\begin{array}{c}-0.01 \\
(0.01)\end{array}$ & $\begin{array}{c}-0.02 \\
(0.01)\end{array}$ \\
\hline Lagged risk preferences & $\begin{array}{c}-0.02 \\
(0.03)\end{array}$ & $\begin{array}{c}-0.05 \\
(0.04)\end{array}$ & $\begin{array}{l}0.03 \\
(0.03)\end{array}$ & $\begin{array}{c}-0.02 \\
(0.03)\end{array}$ \\
\hline HH Value inheritances/bestowal/lottery & $\begin{array}{c}-0.04 \\
(0.06)\end{array}$ & $\begin{array}{l}0.14+ \\
(0.08)\end{array}$ & $\begin{array}{l}0.09 \\
(0.06)\end{array}$ & $\begin{array}{l}0.01 \\
(0.07)\end{array}$ \\
\hline Financial assets share & $\begin{array}{l}0.57 * * * \\
(0.09)\end{array}$ & $\begin{array}{l}0.54 * * * \\
(0.10)\end{array}$ & $\begin{array}{l}0.53 * * * \\
(0.06)\end{array}$ & $\begin{array}{l}0.50 * * * \\
(0.07)\end{array}$ \\
\hline Sell own property & $\begin{array}{c}-4.56^{* * * *} \\
(0.45)\end{array}$ & $\begin{array}{l}-4.94 * * * \\
(0.52)\end{array}$ & $\begin{array}{l}-4.97 * * * \\
(0.33)\end{array}$ & $\begin{array}{c}-5.35 * * * \\
(0.43)\end{array}$ \\
\hline Acquired own property & $\begin{array}{c}-1.04 * * \\
(0.33)\end{array}$ & $\begin{array}{c}-0.54 \\
(0.40)\end{array}$ & $\begin{array}{c}-0.84 * * \\
(0.30)\end{array}$ & $\begin{array}{c}-0.69 * \\
(0.35)\end{array}$ \\
\hline Always tenant & $\begin{array}{l}-4.80 * * * \\
(0.27)\end{array}$ & $\begin{array}{l}-4.81 * * * \\
(0.29)\end{array}$ & $\begin{array}{l}-5.71 * * * \\
(0.24)\end{array}$ & $\begin{array}{l}-5.53 * * * \\
(0.26)\end{array}$ \\
\hline No more consumer credits & $6.30 * * *$ & $5.77 * * *$ & $7.88 * * *$ & $5.60 * * *$ \\
\hline
\end{tabular}




\begin{tabular}{|c|c|c|c|c|}
\hline & $(0.32)$ & $(0.33)$ & $(0.34)$ & $(0.34)$ \\
\hline \multirow[t]{2}{*}{ Acquire consumer credits } & $2.21 * * *$ & $1.46^{* * *}$ & $2.73 * * *$ & 0.07 \\
\hline & $(0.29)$ & $(0.33)$ & $(0.31)$ & $(0.33)$ \\
\hline \multirow[t]{2}{*}{ No consumer credits } & $6.39 * * *$ & $5.80 * * *$ & $7.82 * * *$ & $5.62 * * *$ \\
\hline & $(0.25)$ & $(0.26)$ & $(0.27)$ & $(0.27)$ \\
\hline \multirow[t]{2}{*}{ Lagged tangible assets } & $0.42+$ & $0.79 *$ & $0.38+$ & $0.61+$ \\
\hline & $(0.25)$ & $(0.36)$ & $(0.22)$ & $(0.31)$ \\
\hline \multirow[t]{2}{*}{ Lagged property debts } & -0.03 & 0.16 & 0.08 & -0.14 \\
\hline & $(0.26)$ & $(0.28)$ & $(0.23)$ & $(0.26)$ \\
\hline \multirow[t]{2}{*}{ HH Sell stocks } & $-0.55^{*}$ & -0.38 & $-0.63 * *$ & -0.20 \\
\hline & $(0.25)$ & $(0.29)$ & $(0.22)$ & $(0.26)$ \\
\hline \multirow[t]{2}{*}{ HH Buy stocks } & -0.23 & 0.14 & -0.22 & -0.39 \\
\hline & $(0.28)$ & $(0.35)$ & $(0.25)$ & $(0.32)$ \\
\hline \multirow[t]{2}{*}{ HH No stocks } & $-1.22 * * *$ & $-0.79 * * *$ & $-1.19 * * *$ & $-1.10 * * *$ \\
\hline & $(0.20)$ & $(0.23)$ & $(0.18)$ & $(0.21)$ \\
\hline \multirow[t]{2}{*}{ HH Inheritances/bestowal } & $1.15+$ & -0.95 & -0.26 & -0.04 \\
\hline & $(0.65)$ & $(0.77)$ & $(0.60)$ & $(0.68)$ \\
\hline \multirow[t]{2}{*}{ HH Lottery } & 0.04 & -1.43 & -0.73 & -0.13 \\
\hline & $(0.76)$ & $(0.98)$ & $(0.73)$ & $(0.86)$ \\
\hline \multirow[t]{2}{*}{ HH Saving } & $1.86^{* * *}$ & $2.50 * * *$ & $1.96 * * *$ & $2.43 * * *$ \\
\hline & $(0.22)$ & $(0.25)$ & $(0.18)$ & $(0.22)$ \\
\hline \multirow[t]{2}{*}{ Lagged worried for financial reasons } & $-0.55 * * *$ & $-0.42 * *$ & $-0.43 * * *$ & $-0.53 * * *$ \\
\hline & $(0.12)$ & $(0.13)$ & $(0.10)$ & $(0.12)$ \\
\hline \multirow[t]{2}{*}{ Constant } & -0.56 & $4.01+$ & -0.67 & 0.24 \\
\hline & $(2.06)$ & $(2.16)$ & $(1.60)$ & $(1.95)$ \\
\hline Adj. R2 & 0.45 & 0.46 & 0.50 & 0.47 \\
\hline Observations & 5,240 & 3,813 & 5,824 & 4,388 \\
\hline
\end{tabular}

Note: + p-value $<0.10 ; *$ p-value $<0.05 ; * *$-value $<0.01 ; * * *$-value $<0.001$. Standard errors in parentheses. Controlling for missing variables. Reference categories: German, lagged low educated, West Germany, lagged blue collar, always married, always own property, always consumer credits, HH hold stocks. HH stands for household. Source: SOEPv30, individuals aged 25-64. Panel samples 2002-2007 and 2007-2012 are used. 
Table. A.3 Regression of overall population aged 25-64, by gender. Short regressions, without occupational status

\begin{tabular}{|c|c|c|c|c|}
\hline$y=I H S$ wealth & Men 2007 & Men 2012 & Women 2007 & Women 2012 \\
\hline Migrant & $\begin{array}{l}-2.11 * * * \\
(0.25)\end{array}$ & $\begin{array}{l}-1.67 * * * \\
(0.31)\end{array}$ & $\begin{array}{l}-2.09 * * * \\
(0.23)\end{array}$ & $\begin{array}{c}-1.47^{* * * *} \\
(0.28)\end{array}$ \\
\hline Age & $\begin{array}{l}0.08 \\
(0.08)\end{array}$ & $\begin{array}{c}-0.03 \\
(0.10)\end{array}$ & $\begin{array}{l}0.11 \\
(0.08)\end{array}$ & $\begin{array}{l}0.11 \\
(0.09)\end{array}$ \\
\hline Age squared & $\begin{array}{l}0.00 \\
(0.00)\end{array}$ & $\begin{array}{l}0.00 \\
(0.00)\end{array}$ & $\begin{array}{c}-0.00 \\
(0.00)\end{array}$ & $\begin{array}{l}0.00 \\
(0.00)\end{array}$ \\
\hline Num. of children & $\begin{array}{c}-0.14 \\
(0.27)\end{array}$ & $\begin{array}{c}-0.05 \\
(0.32)\end{array}$ & $\begin{array}{c}-0.06 \\
(0.25)\end{array}$ & $\begin{array}{c}-0.69 * \\
(0.30)\end{array}$ \\
\hline Lagged lower voc. education & $\begin{array}{l}0.53+ \\
(0.28)\end{array}$ & $\begin{array}{l}1.19 * * * \\
(0.35)\end{array}$ & $\begin{array}{l}1.57 * * * \\
(0.24)\end{array}$ & $\begin{array}{l}1.29 * * * \\
(0.31)\end{array}$ \\
\hline Lagged upper voc. education & $\begin{array}{l}1.18 * * * \\
(0.34)\end{array}$ & $\begin{array}{l}2.13 * * * \\
(0.42)\end{array}$ & $\begin{array}{l}2.16^{* * * *} \\
(0.30)\end{array}$ & $\begin{array}{l}2.06^{* * * *} \\
(0.37)\end{array}$ \\
\hline Lagged university & $\begin{array}{l}1.71 * * * \\
(0.32)\end{array}$ & $\begin{array}{l}2.81 * * * \\
(0.40)\end{array}$ & $\begin{array}{l}2.90 * * * \\
(0.30)\end{array}$ & $\begin{array}{l}3.01 * * * \\
(0.36)\end{array}$ \\
\hline East Germany & $\begin{array}{l}-0.82 * * * \\
(0.22)\end{array}$ & $\begin{array}{l}-1.22 * * * \\
(0.24)\end{array}$ & $\begin{array}{l}-1.02 * * * \\
(0.21)\end{array}$ & $\begin{array}{l}-1.14 * * * \\
(0.23)\end{array}$ \\
\hline Full time employment (months) & $\begin{array}{l}0.03 * * * \\
(0.01)\end{array}$ & $\begin{array}{l}0.03 * * \\
(0.01)\end{array}$ & $\begin{array}{l}0.02 * * \\
(0.01)\end{array}$ & $\begin{array}{l}0.01 \\
(0.01)\end{array}$ \\
\hline Part time employment (months) & $\begin{array}{l}0.01 \\
(0.01)\end{array}$ & $\begin{array}{c}-0.00 \\
(0.01)\end{array}$ & $\begin{array}{l}0.01 * \\
(0.01)\end{array}$ & $\begin{array}{l}0.02 * * \\
(0.01)\end{array}$ \\
\hline Long term unemployment & $\begin{array}{l}-2.66^{* * *} \\
(0.33)\end{array}$ & $\begin{array}{l}-3.07 * * * \\
(0.42)\end{array}$ & $\begin{array}{l}-2.96 * * * \\
(0.28)\end{array}$ & $\begin{array}{l}-2.63 * * * \\
(0.34)\end{array}$ \\
\hline Lagged Not employed & $\begin{array}{l}1.01 \\
(0.81)\end{array}$ & $\begin{array}{l}0.55 \\
(0.86)\end{array}$ & $\begin{array}{c}-0.23 \\
(0.29)\end{array}$ & $\begin{array}{l}0.62+ \\
(0.34)\end{array}$ \\
\hline IHS permanent income & $\begin{array}{l}0.84 * * * \\
(0.11)\end{array}$ & $\begin{array}{l}0.33 * * * \\
(0.09)\end{array}$ & $\begin{array}{l}0.00 \\
(0.04)\end{array}$ & $\begin{array}{l}0.14 * * \\
(0.05)\end{array}$ \\
\hline Married to widowed & $\begin{array}{l}1.42 \\
(1.82)\end{array}$ & $\begin{array}{l}3.23 \\
(1.99)\end{array}$ & $\begin{array}{l}0.55 \\
(0.92)\end{array}$ & $\begin{array}{c}-1.78+ \\
(1.00)\end{array}$ \\
\hline Married to divorced/separated & $\begin{array}{l}-2.30 * * * \\
(0.51)\end{array}$ & $\begin{array}{l}-2.22 * * * \\
(0.63)\end{array}$ & $\begin{array}{l}-2.59 * * * \\
(0.45)\end{array}$ & $\begin{array}{l}-2.33 * * * \\
(0.58)\end{array}$ \\
\hline Never Married to married & $\begin{array}{c}-0.43 \\
(0.49)\end{array}$ & $\begin{array}{c}-0.06 \\
(0.57)\end{array}$ & $\begin{array}{c}-0.92+ \\
(0.48)\end{array}$ & $\begin{array}{l}0.39 \\
(0.55)\end{array}$ \\
\hline Always never married & $\begin{array}{l}-2.01 * * * \\
(0.50)\end{array}$ & $\begin{array}{c}-1.75^{* *} \\
(0.57)\end{array}$ & $\begin{array}{l}-2.52 * * * \\
(0.46)\end{array}$ & $\begin{array}{l}-2.78 * * * \\
(0.52)\end{array}$ \\
\hline Single to married & $\begin{array}{c}-0.04 \\
(0.56)\end{array}$ & $\begin{array}{c}-1.10+ \\
(0.64)\end{array}$ & $-1.61 * *$ & $\begin{array}{c}-0.43 \\
(0.59)\end{array}$ \\
\hline Single (other) & $-1.93 * * *$ & $\begin{array}{l}-1.32 * * \\
(0.50)\end{array}$ & $-2.27 * * *$ & $\begin{array}{l}-2.52 * * * \\
(0.43)\end{array}$ \\
\hline Num. of marriages & $\begin{array}{l}-1.37 * * * \\
(0.23)\end{array}$ & $\begin{array}{l}-1.66^{* * * *} \\
(0.27)\end{array}$ & $\begin{array}{l}-0.97 * * * \\
(0.20)\end{array}$ & $\begin{array}{l}-1.52 * * * \\
(0.22)\end{array}$ \\
\hline Length & $\begin{array}{l}0.01 \\
(0.01)\end{array}$ & $\begin{array}{l}0.02 \\
(0.02)\end{array}$ & $\begin{array}{l}0.00 \\
(0.01)\end{array}$ & $\begin{array}{c}-0.00 \\
(0.01)\end{array}$ \\
\hline Lagged risk & $\begin{array}{c}-0.02 \\
(0.04)\end{array}$ & $\begin{array}{c}-0.03 \\
(0.05)\end{array}$ & $\begin{array}{l}0.01 \\
(0.04)\end{array}$ & $\begin{array}{c}-0.04 \\
(0.04)\end{array}$ \\
\hline HH Value inheritances/bestowal/lottery & $\begin{array}{l}0.13 * * * \\
(0.02)\end{array}$ & $\begin{array}{l}0.09 * * \\
(0.03)\end{array}$ & $\begin{array}{l}0.17 * * * \\
(0.02)\end{array}$ & $\begin{array}{l}0.10^{* * *} \\
(0.02)\end{array}$ \\
\hline Financial assets share & $\begin{array}{l}0.51 * * * \\
(0.10)\end{array}$ & $\begin{array}{l}0.51 * * * \\
(0.11)\end{array}$ & $\begin{array}{l}0.45^{* * *} \\
(0.08)\end{array}$ & $\begin{array}{l}0.48 * * * \\
(0.09)\end{array}$ \\
\hline Constant & $\begin{array}{c}-4.53 * \\
(2.20) \\
\end{array}$ & $\begin{array}{l}2.65 \\
(2.36) \\
\end{array}$ & $\begin{array}{l}3.02+ \\
(1.83) \\
\end{array}$ & $\begin{array}{l}2.05 \\
(2.17) \\
\end{array}$ \\
\hline $\begin{array}{l}\text { Adj. R2 } \\
\text { Observations }\end{array}$ & $\begin{array}{c}0.21 \\
5,240\end{array}$ & $\begin{array}{c}0.20 \\
3,813\end{array}$ & $\begin{array}{l}0.18 \\
5,824\end{array}$ & $\begin{array}{c}0.17 \\
4,388\end{array}$ \\
\hline
\end{tabular}

Source: SOEPv30, individuals aged 25-64. Panel samples 2002-2007 and 2007-2012 are used.

Note: + p-value $<0.10 ; *$ p-value $<0.05 ; * *$ p-value $<0.01 ; * *$ p-value $<0.001$. Standard errors in parentheses.

Controlling for missing variables. Reference categories: German, lagged low educated, West Germany, always married.

HH stands for household. 


\section{APPENDIX B}

\section{Control variables}

In the following section, the control variables are described. Note that when we used the "lagged variable", it means that we are exploiting the information of 5 years before (e.g. information from 2002 in 2007, and from 2007 in 2012). We also define changes in marital status, own property status, consumer credits, and stocks, which are defined comparing the status in year 1 (e.g. 2002, or 2007) and year 2 (2007 or 2012).

Socio-demographic variables: migration status (German - ref. group - or migrant background), age and age squared, number of children under 5 years old in the household, a dummy equal to 1 if living in East Germany.

Lagged level of education: low educated (ISCED 0, 1, 2), lower vocational (ISCED 3), upper vocational (ISCED 4, 5), university (ISCED 6); if the individual is still in education, the next completed level of education is imputed as lagged.

Marital history: number of marriages, length of current marriage.

Employment history: months spent in full-time employment in the previous 5 years, months spent in part-time employment in the previous 5 years, and a dummy for long term unemployement, equal to 1 if the person spent 12 months or more in unemployement.

Lagged occupational status: categorical variables: not employed, trainee $(=1$ if military, apprentice or trainee), self-employment, white collar (employee), blue collar (=1 if untrained, trained or semitrained worker, foreman; ref. group), low civil servants (low and middle), high civil servants (high and executive).

Permanent income: (inverse hyperbolic sine transformation) of 5-years average of individual total income (individual labor earnings, unemployment benefits, old age or other pensions, subsistence allowance, maternity benefit, student grants, alimony, company or private pension).

Lagged permanent income of the spouse: defined as above, but for the spouse (included only in specifications for married people).

Bargaining power: this variable is constructed as the ratio among the personal permanent income and the permanent income of the couple (partner permanent income added to the personal one). included only in specifications for married people.

Lagged risk preferences: self-defined, answering to the question "Are you generally a person who is fully prepared to take risks or do you try to avoid taking risks?", and the possible answer are from 0 to 10 . Since the preference for risk is not collected every year, we use information from 2004 for 2002, and from 2008 for 2007 (or 2006 if missing in 2008).

HH Inheritance/bestowals; HH lottery: takes value 1 if the household had inheritances (/lottery) in the previous 5 years (for the previous 3 years in 2002).

HH value of inheritances/bestowals/lottery: amount of inheritances/bestowals/lottery received in the previous 5 years (for the estimations, the inverse hyperbolic sine transformation is applied).

HH savings: is a dummy variable equal to 1 if the household was able to save regularly at least for one year in the previous 5 .

Financial assets share: is constructed using the ratio among financial assets and non-financial assets, interacted by a dummy which takes value 1 if the household have stocks (because fin. assets can also be savings accounts).

Lagged worried for financial reasons: every year, individuals are asked to answer to the question "are you concerned with your own economic situation?". The variable, in our setup, takes value 1 if the person is not concerned at all, 2 if she is somewhat concerned, 3 if very concerned. Missing values are imputed with value 2. 


\section{Changes in status:}

Marital status: the individual can be always married (ref. category), can become widowed from married, divorced or separated from married; she can be always never married, or got married if she was previously never married, or previously single (widowed/divorced/separated). She is considered "single (other)" if she remained widowed, divorced or separated, or if she had any change among there 3 categories, or from never married into separated.

Property: the individual can be always owner (ref. category), sell the property, acquire property, or be always tenant.

Consumer credits: the individual can have consumer credits in both periods (ref. category), get rid of them, take out consumer credits, or never have consumer credits.

Stocks: the household can have stocks in both periods (ref. category), selling them, acquire them, or never have stocks.

In addition, we also include some "missing variables": the appropriate variable is imputed, and the "missing variable" takes value 1 . "Missing employment" takes value 1 if the employment history or the occupational category was missing; "missing bequest" takes value 1 if the inheritance, gifts, lottery (or their value), saving variable is missing, "missing personal" takes 1 if variables for education, marital status or marital history, migration background, risk preference, are missing.

When we perform the Oaxaca-Blinder decomposition and the Firpo, Fortin, Lemieux decomposition, the explanatory variables are grouped in the following way:

Migration: migratory status;

Age: age and age squared;

Kids: number of children;

Education: lagged level of education;

Residence: residence in East Germany;

Labor market participation: labour market (full time, parttime, unemployment, not employed);

Occupation: lagged occupational status (trainee, self empl., white collar, civil servants low or high);

Income: personal permanent permanent income;

Marital status: changes in marital status;

Other marital variables: number of marriages and length of current marriage;

Risk preferences: lagged risk preferences;

HH value inerit./bestowal/lottery: value of inheritances/bestowal/lottery;

Financial assets share: financial assets share;

Other (missing): missing variables. 